\title{
Enflasyon-Faiz Oranı Takası: Fisher Hipotezi Bağlamında Türkiye Ekonomisi İçin Dinamik En Küçük Kareler Yöntemi
}

\author{
Merter AKINCI, Department of Economics, Unye Faculty of Economics and Administrative Sciences, Ordu \\ University, Turkey; e-mail: makinci86@ gmail.com
}

Ömer YILMAZ, Department of Econometrics, Faculty of Economics and Administrative Sciences, Ataturk University,Turkey; e-mail: omeryilmaz@atauni.edu.tr

\section{The Trade-Off between Inflation and Interest Rate: A Dynamic Least Squares Method for Turkish Economy in the Context of Fisher Hypothesis}

\begin{abstract}
In this study, the Dynamic Ordinary Least Squares (DOLS) analysis is applied to test the impact of inflation on interest rate directly and indirectly with the help of six control variables for Turkish economy in the period 1980-2012. First of all, Johansen-Juselius cointegration test is applied in order to determine the long-run relationships among the variables and the results show the validity of long-run nexus among the variables. Granger causality test is applied to determine the causal relationships among the variables and the causal linkages among the variables are found that are compatible with the expectations. The findings of the DOLS analysis indicate that inflation rate, current account balance, external debt service, Money supply, exchange rate and process of economic growth have statistically significant effects on the interest rate.
\end{abstract}

Keywords

Generalized Fisher Hypothesis, Time Series Analysis, Dynamic Least Square Analysis.

JEL Classification Codes : C32, E31, E43.

\section{$\ddot{\mathbf{O z}}$}

$\mathrm{Bu}$ çalışmada, enflasyonun faiz oranı üzerindeki etkilerini doğrudan ve altı kontrol değişkeni yardımıyla dolaylı olarak Türkiye ekonomisinde 1980-2012 dönemi için test edebilmek amacıyla Dinamik En Küçük Kareler (DOLS) analizi kullanılmıştır. İlk olarak, ilgili değişkenlere uygulanan Johansen-Juselius eşbütünleşme testi sonucunda, uzun dönemli ilişkiler elde edilmiştir. Değişkenler arasında nedensellik ilişkilerini belirleyebilmek için Granger nedensellik testi uygulanmış ve beklentilerle uyumlu olan nedensellik ilişkilerinin varlığı kanıtlanmıştır. DOLS analizi tahmin sonuçları; enflasyon, cari denge, dış borç servisi, para arzı, döviz kuru ve ekonomik büyüme sürecinin faiz oranı üzerinde istatistiki bakımdan anlamlı etkiler yarattığını ortaya koymuştur.

\section{Anahtar Sözcükler $\quad$ : Genelleştirilmiş Fisher Hipotezi, Zaman Serisi Analizi, Dinamik En Küçük Kareler Analizi.}


Akınc1, M. \& Ö. Yılmaz (2016), "Enflasyon-Faiz Oranı Takası: Fisher Hipotezi Bağlamında Türkiye Ekonomisi İçin Dinamik En Küçük Kareler Yöntemi”, Sosyoekonomi, Vol. 24(27), 33-55.

\section{Giriş}

Enflasyon ve faiz arasındaki ilişkilerin tespit edilmesi ekonomistlerin ve politika yapımcıların uzunca bir zamandan beri ilgisini çeken en önemli konulardan bir tanesi olmuş ve başta tüm ülke ekonomilerini olmak üzere, özellikle Türkiye gibi gelişmekte olan ve azgelişmiş ülkeleri yakından ilgilendiren enflasyon-faiz oranı sarmalı, son yıllarda küresel ekonomi gündeminde adından daha fazla söz ettirmeye başlamıştır. Adı geçen makroekonomik değişkenler arasındaki dinamik ilişkiler ilk kez Amerikalı iktisatçı Irving Fisher $(1896,1930)$ tarafından sistematik bir şekilde incelendiğinden dolayı literatürde "Fisher Hipotezi" olarak adlandırılmıştır.

Türkiye ekonomisinde, ifade edilen değişkenlerin hangisinin daha baskın olduğu ve nedensellik ilişkisi göz önüne alındığında "sebep" bağını oluşturan unsurun hangi faktörden kaynaklandığı yoğun bir tartışma konusu olduğundan dolayı, ekonomik yapımız bakımından ilgili değişkenler arasındaki ilişkilerin incelenmesi zaruri olarak görülmektedir. Uzun dönemli denge düzeyinde para arzı büyüme oranındaki bir değişimin enflasyon oranını uyaracağını ortaya koyan Fisher Hipotezi dikkate alındığında, fiyatlar genel düzeyinde meydana gelen bir değişimin de nominal faiz oranlarına yansıyacağı fikri dikkate alınmaktadır. Burada üzerinde durulması gereken temel nokta, faiz oranlarındaki değişim sonucunda beklenen enflasyonun değil, beklenen enflasyon oranlarında meydana gelen bir değişimin nominal faiz oranlarını etkileyeceğidir. Dolayısıyla bu çalışmanın amacı, enflasyon ve faiz oranı arasındaki ilişkileri Türkiye ekonomisinde 1980-2012 dönemi yıllık verileri itibariyle Dinamik En Küçük Kareler (DOLS) Analizi yardımıyla incelemektir. Söz konusu bu çalışmayı literatürde yer alan ve Türkiye ekonomisi için yapılan diğer çalışmalardan üstün kılan temel özellik ise, enflasyon-faiz oranı arasındaki ilişkilerin sadece bu iki değişkenden ziyade analizlerin sağlamlılığını ortaya koyacak ilave altı değişken (cari denge, dış borç servisi, gayri safi yurtiçi tasarruflar, para arzı, döviz kuru ve ekonomik büyüme) eklenerek sınanmasıdır. Belirtilen ilave bağımsız değişkenler, gerek ulusal ve gerekse uluslararası literatürün taranması suretiyle saptanmış ve dikkate alınan her ilave değişkenin enflasyon oranını etkilemek suretiyle faiz oranlarına yansıyacağı düşünülmüştür. İfade edilen bu özellik, çalışmanın geniş bir makroekonomik tabanı bünyesinde barındırmasından dolayı literatüre doğrudan bir katkı sağlamayı hedeflemektedir. Ayrıca, DOLS analizi kapsamında ilgili değişkenlerin cari ve geçmiş dönem değerlerinin analizlere dâhil edilmesi, dinamik bir süreç ile çözümleme olanağı sağlamakta ve daha güvenilir sonuçlar elde edilmesine yardımcı olmaktadır. Bu kapsam dâhilinde çalışma altı bölümden oluşmaktadır. Konunun teorik temellerinin ortaya konduğu ikinci bölümü takiben, Fisher hipotezi kapsamında literatürde yapılan çalışmalar üçüncü bölümde sunulacaktır. Çalışmanın dördüncü bölümünde analizlere ilişkin veri seti ve model tanıtılacak, uygulama bulguları ise beşinci bölümde yer alacaktır. Çalışma, genel bir değerlendirmenin yapıldığı sonuç bölümüyle sona erdirilecektir. 


\section{Fisher Hipotezi Ekseninde Enflasyon-Faiz Oranı Bağlantıları}

Fisher Hipotezi, üç temel yaklaşım yardımıyla incelenmektedir. Bunlar; Yurtiçi Fisher Hipotezi, Genelleştirilmiş Fisher Hipotezi ve Uluslararası Fisher Hipotezi'dir. Yurtiçi Fisher Hipotezi, bir ekonomideki nominal faiz oranının, reel faiz oranı ile beklenen enflasyon oranı toplamından oluşacağını belirtmektedir. Ancak bu hipotez, reel faiz oranlarının ekonomi politikasındaki değişimlerden etkilenebileceği dikkate alındığında her zaman geçerli olmayabilmektedir. Diğer şartlar sabitken, ceteris paribus; nominal faiz oranı, reel faiz oranı ve enflasyon oranı arasındaki ilişkiler aşağıdaki (1) numaralı eşitlik yardımıyla gösterilebilir (Granville \& Mallick, 2004: 87):

$$
1+r_{t}=\frac{1+i_{t}}{1+\pi_{t}}
$$

(1) numaralı eşitlikte $i_{t}$, nominal faiz oranını; $\pi_{t}$, enflasyon oranını ve $r_{t}$ ise reel faiz oranını temsil etmektedir. $r_{t}$ dikkate alınarak yeni bir çözüm oluşturulduğunda,

$$
r_{t}=\frac{i_{t}-\pi_{t}}{1+\pi_{t}}
$$

eşitliği elde edilir. (2) numaralı eşitlikte paydanın göz ardı edildiği ve reel faiz oranının da sabit olduğu varsayımı dikkate alınırsa, dönem başı beklenen enflasyon $\left(\pi_{t}^{e}\right)$, nominal faiz oranının temel belirleyicisi konumunda olur. Bu bağlamda nominal faiz oranı, reel faiz oranı ile beklenen enflasyon oranının toplamından oluşur:

$$
i_{t}=r+\pi_{t}^{e}
$$

Fisher Hipotezi'nin ikinci yorumlama biçimi ise, dışa açık ülkelerin dikkate alınmış şeklidir ve buna Genelleştirilmiş Fisher Etkisi veya Fisher Açık denir. Genelleştirilmiş Fisher Etkisi, iki ülke arasındaki nominal faiz oranları farkının, ilgili ülkelerin beklenen enflasyon oranları farkına eşit olduğunu ifade eder. $X$ ve $Y$ gibi iki ülke dikkate alındığında Genelleştirilmiş Fisher Koşulu şöyle gösterilebilir:

$$
i_{X}-i_{Y}=\pi_{X}-\pi_{Y}
$$

(4) numaralı eşitlikte $i_{X}$ ve $i_{Y}$ sırasıyla $X$ ve $Y$ ülkelerindeki nominal faiz oranlarını, $\pi_{X}$ ve $\pi_{Y}$ ise sirasıyla $X$ ve $Y$ ülkelerindeki beklenen enflasyon oranlarını ifade etmektedir. Fisher, bir ekonomideki reel ve parasal sektörlerin bağımsız olduklarına 
inandığından dolayı, reel getiri oranlarının reel faktörler ve mali getiri oranlarının ise parasal faktörler tarafından belirlendiği görüşünü savunmuştur. Bu bağlamda (4) numaralı eşitlik, beklenen enflasyon oranının yüksek olduğu bir ekonomide nominal faiz oranının da o ölçüde yüksek olacağını belirtmektedir. Bu durumun temel nedeni, reel varlıklar ile mali varlıklar arasındaki arbitraj mekanizmasıdır. Beklenen enflasyon oranının yüksek ancak faiz getirilerinin düşük olduğu bir durumda karar birimleri mali varlıklardan ziyade reel varlıklara yönelirler. Tersine, beklenen enflasyon oranının düşük olduğu ve bu düşüşün faizlere yansımadığı bir durumda ise mali varlıklara yatırım tercih edilir. Ayrıca, bir ülkedeki reel faiz getirisinin diğer ülkelere kıyasla daha yüksek olması durumunda, kısa vadeli fonlar reel faizi düşük olandan yüksek olana doğru yönelecektir. Reel faizler eşitlendiğinde ise iki ülke arasındaki nominal faiz oranı farkı, beklenen enflasyon oranına eşit olacaktır.

Arbitraj mekanizmasının yanı sıra, enflasyon oranlarının yüksek olduğu dönemlerde yatırım kararlarına ilişkin gelecek dönem beklentilerini kesin bir yargıyla belirlemek mümkün olmadığından dolayı, yatırımcıların kâr ve maliyet hesaplamalarını yapmaları zorlaşmaktadır. Riskten korunma arzusunda olan yatırımcıların yüksek bir gelir beklentisi içinde olmaları ise faiz oranları üzerinde yukarı yönlü etkileri tetiklemektedir. Diğer taraftan, yüksek enflasyon oranlarının hüküm sürdüğü konjonktür dönemlerinde dış piyasalarda rekabetçi düzey bozulmakta ve potansiyel ihraç malları pahalılaştığından dolayı ihracat kapasitesi azalmaktadır. İthalat hacmi veri olarak dikkate alınsa bile, cari açık problemine veya mevcut cari açık seviyesinin yükselmesine neden olan bu durum, yabancı yatırım ve sermayenin ülkeye gelmesine büyük bir darbe vurmaktadır. Maliyet dezavantajı ve belirsizlik ortamının ortaya çıkardığı istikrarsız süreç, yüksek faiz ve artan seviyedeki risk primi vasıtasıyla telafi edilmeye çalışılmaktadır. Bu bağlamda; arbitraj mekanizması, yatırım kararlarında geleceğin öngörülememesi, diş pazarlarda azalan rekabet gücü dolayısıyla kendini gösteren cari açık problemi ve döviz kurlarındaki dalgalanmalara bağlı olarak enflasyon ve faiz oranları arasında bire-bir ilişkilerin ortaya çıkması beklenmektedir.

Fisher etkisi kapsamında üçüncü ve son olarak, iki ülke arasındaki nominal faiz oranı farkının, bu ülkelerdeki beklenen döviz kuru değişimine ilişkin bilgileri yansıtacağını belirtmektedir. Bu bağlamda, faiz oranları ile döviz kurları arasındaki ilişkilere Uluslararası Fisher Etkisi adı verilmektedir. Uluslararası Fisher Etkisi, Genelleştirilmiş Fisher Etkisi ile göreceli Satın Alma Gücü Paritesinin kombine edilmiş bir şeklidir. Göreceli Satın Alma Gücü Paritesi, iki ülke arasındaki beklenen enflasyon oranının, beklenen döviz kurundaki değişime eşit olacağı biçiminde yorumlanmakta ve (5) numaralı eşitlik yardımıyla gösterilmektedir:

$$
\pi_{X}-\pi_{Y}=\frac{S_{t+1}-S_{t}}{S_{t}}
$$


(5) numaralı eşitlikte $S_{t}$ ve $S_{t+1}$ terimleri sırasıyla cari ve bir sonraki dönem spot döviz kurlarını yansıtmaktadırlar. (4) ve (5) numaralı eşitlikler bir araya getirildiğinde Uluslararası Fisher ilişkisi,

$$
\pi_{X}-\pi_{Y}=i_{X}-i_{Y}=\frac{S_{t+1}-S_{t}}{S_{t}}
$$

biçiminde yazılabilir. Bu eşitlik, ülkeler arasındaki enflasyon oranları ile nominal faiz oranlarının beklenen döviz kurlarındaki değişimi yansıttığını ortaya koymaktadır. Bu bağlamda, enflasyon oranı yüksek olan ülkede faiz oranları da o ölçüde artacak ve döviz kuru buna paralel olarak yükselecek, yani ulusal para değer kaybedecektir (Demirag ve Goddard, 1995: 76).

\section{Literatür Özeti}

İktisat literatüründe Fisher Hipotezi'ni test edebilmek amacıyla ortaya konulan çok sayıda çalışma bulunmaktadır. Yapılan uygulamalı analizlerin çoğu Genelleştirilmiş Fisher Hipotezi'nin geçerli olup olmadığını belirlemeye çalışmış ve bu çalışmaların büyük bir kısmı enflasyon oranının faiz oranı üzerinde pozitif yönlü etkiler yarattığını ortaya koymasına karşın, bir kısmı ise böyle bir ilişkinin söz konusu olmadığını göstermiştir. ABD ekonomisi için Barthold ve Dougan (1986), Hutchison ve Keeley (1989), Gupta (1991), Pelaez (1995), Daniels vd. (1996), Choi (2002), Sun ve Phillips (2004) ve Million (2004); dört gelişmiş ülke için McDonald ve Murphy (1989); İngiltere ekonomisi için Woodward (1992); yüksek enflasyon sorunu bulunan üç ülke için Phylaktis ve Blake (1993) ve Carneiro vd. (2002); sanayileşmiş beş ülke için Peng (1995); Avustralya ekonomisi için Olekalns (1996); Danimarka ekonomisi için Engsted (1996); Kanada ekonomisi için Crowder (1997); Finlandiya ekonomisi için Junttila (2001); 26 ülke için Berument ve Jelassi (2002); Kanada ve ABD ekonomileri için Atkins ve Coe (2002) ve Atkins ve Chan (2004); G7 ülkeleri için Lardic ve Mignon (2003); G7 ve sekiz Asya ülkesi için Wong ve Wu (2003); 16 OECD ülkesi için Madsen (2005); 100 ülke için Herwartz ve Reimers (2006); 32 gelişmiş ve gelişmekte olan ülke için Kasman vd. (2006); G7 ve 45 gelişmekte olan ülke için Berument vd. (2007) ve 15 gelişmiş ülke için Beyer vd. (2009) tarafından yapılan çalışmalar Fisher Hipotezi'nin geçerli olduğunu gösteren bulguları ortaya koymuştur.

Enflasyon oranı ile faiz oranı arasında pozitif yönlü bire bir ilişki olduğunu ortaya koyan çalışmaların yanı sıra, ilgili değişkenler arasında herhangi bir nedenselliğin olmadığı sonucunu gösteren çalışmalar da mevcuttur. ABD ekonomisi için Jaffe ve Mandelker (1976), Summers (1982), Graham (1988) ve Mishkin (1993); gelişmiş altı ülke için Cumby (1980) ve Kane vd. (1983); 26 ülke için Gültekin (1983); Kananda ekonomisi için Moazzami (1991) ve Dutt ve Ghosh (1995); Avustralya ekonomisi için Inder ve Silvapulle (1993); Finlandiya ekonomisi için Linden (1995); 40 ülke için Coppock ve Poitras (2000); ve Japonya 
ekonomisi için Ito (2009) tarafindan yapılan çalışmalar Fisher Hipotezi'nin geçerli olmadığını göstermiştir.

Fisher Hipotezi'ni Türkiye ekonomisi için test eden çalışmalar az sayıda olmakla birlikte, yapılan analizlerde ortak bir sonuca ulaşılamamıştır. Kutan ve Aksoy (2003), Turgutlu (2004) ve Şimşek ve Kadılar (2006) tarafından yapılan çalışmalar Fisher Hipotezi'nin geçerli olduğunu ortaya koymalarına karşın; Çakmak vd. (2002), Gül ve Açıkalın (2008) ve Yılancı (2009) tarafından yapılan çalışmalar ise enflasyon oranının faiz oranı üzerinde herhangi bir etkisinin olmadığını göstermiştir. Uygulamalı çalışmalara ait literatür özeti Tablo 1'de sunulmuştur.

Tablo: 1

Fisher Hipotezini Uygulamalı Olarak Test Eden Çalışmalara İlişkin Literatür Özeti

\begin{tabular}{|c|c|c|c|c|}
\hline \multicolumn{5}{|c|}{ Fisher Hipotezinin Geçerliliğini Gösteren Çalışmalar } \\
\hline Yazar(lar) & Yöntem & Dönem & Ülke & Sonuc \\
\hline $\begin{array}{l}\text { Barthold \& } \\
\text { Dougan } \\
\text { (1986) }\end{array}$ & $\begin{array}{l}\text { Zaman Serisi } \\
\text { Analizi }\end{array}$ & $\begin{array}{c}1902- \\
1983\end{array}$ & $\mathrm{ABD}$ & Enflasyon $\rightarrow$ Faiz \\
\hline $\begin{array}{l}\text { Hutchison } \\
\& \\
\text { Keeley } \\
(1989)\end{array}$ & $\begin{array}{l}\text { Zaman Serisi } \\
\text { Analizi }\end{array}$ & $\begin{array}{c}1953- \\
1986\end{array}$ & $\mathrm{ABD}$ & Enflasyon $\rightarrow$ Faiz \\
\hline $\begin{array}{l}\text { McDonald } \\
\& \\
\text { Murphy } \\
(1989)\end{array}$ & $\begin{array}{l}\text { Vektör Hata } \\
\text { Düzeltme } \\
\text { Modeli }\end{array}$ & $\begin{array}{c}1955- \\
1986\end{array}$ & $\begin{array}{l}\text { Gelişmiş } \\
\text { Dört Ülke }\end{array}$ & $\begin{array}{l}\text { Enflasyon } \rightarrow \text { Faiz, Enflasyonun Faiz Oranı Üzerinde Pozitif Yönlü } \\
\text { Etkisi Vardır }\end{array}$ \\
\hline $\begin{array}{l}\text { Gupta } \\
(1991)\end{array}$ & $\begin{array}{l}\text { Zaman Serisi } \\
\text { Analizi }\end{array}$ & $\begin{array}{l}1968: Q 4 \\
1985: Q 4\end{array}$ & $\mathrm{ABD}$ & Enflasyon $\rightarrow$ Faiz \\
\hline $\begin{array}{l}\text { Woodward } \\
(1992)\end{array}$ & $\begin{array}{l}\text { Zaman Serisi } \\
\text { Analizi }\end{array}$ & $\begin{array}{l}1982: 04 \\
1990: 08\end{array}$ & İngiltere & Enflasyon $\rightarrow$ Faiz \\
\hline $\begin{array}{l}\text { Phylaktis } \\
\& \\
\text { Blake } \\
(1993)\end{array}$ & $\begin{array}{l}\text { Vektör Hata } \\
\text { Düzeltme } \\
\text { Modeli }\end{array}$ & $\begin{array}{l}\text { 1971:Q1 } \\
1991: Q 3\end{array}$ & $\begin{array}{l}\text { Arjantin, } \\
\text { Brezilya, } \\
\text { Meksika }\end{array}$ & $\begin{array}{l}\text { Enflasyonun Faiz Oranı Üzerinde Pozitif Yönlü Etkisi Vardır, } \\
\text { Değişkenler Arasında Eşbütünleşme İlişkisi Söz Konusudur }\end{array}$ \\
\hline $\begin{array}{l}\text { Peng } \\
(1995)\end{array}$ & $\begin{array}{l}\text { Zaman Serisi } \\
\text { Analizi }\end{array}$ & $\begin{array}{l}\text { 1957:Q1 } \\
1994: Q 2\end{array}$ & $\begin{array}{l}\text { Sanayileşmiş } \\
\text { Beş Ülke }\end{array}$ & $\begin{array}{l}\text { Enflasyon } \rightarrow \text { Faiz, Enflasyonun Faiz Oranı Üzerinde Pozitif Yönlü } \\
\text { Etkisi Vardır }\end{array}$ \\
\hline $\begin{array}{l}\text { Pelaez } \\
(1995)\end{array}$ & $\begin{array}{c}\text { Johansen } \\
\text { Eşbütünleşme } \\
\text { Analizi }\end{array}$ & $\begin{array}{l}\text { 1959:Q1 } \\
1993: Q 4\end{array}$ & $\mathrm{ABD}$ & $\begin{array}{l}\text { Enflasyonun Faiz Oranı Üzerinde Pozitif Yönlü Etkisi Vardır, } \\
\text { Değişkenler Arasında Eşbütünleşme İlişsisi Söz Konusudur }\end{array}$ \\
\hline $\begin{array}{l}\text { Olekalns } \\
(1996)\end{array}$ & $\begin{array}{l}\text { Zaman Serisi } \\
\text { Analizi }\end{array}$ & $\begin{array}{l}1965- \\
1990\end{array}$ & Avustralya & $\begin{array}{l}\text { Enflasyon } \rightarrow \text { Faiz, Enflasyonun Faiz Oranı Üzerinde Pozitif Yönlü } \\
\text { Etkisi Vardır }\end{array}$ \\
\hline $\begin{array}{l}\text { Daniels vd. } \\
\text { (1996) }\end{array}$ & $\begin{array}{l}\text { Johansen } \\
\text { Eşbütünleşme } \\
\text { Analizi }\end{array}$ & $\begin{array}{l}\text { 1957:Q1 } \\
1992: Q 4\end{array}$ & $\mathrm{ABD}$ & $\begin{array}{l}\text { Enflasyon } \rightarrow \text { Faiz, Değişkenler Arasında Eşbütünleşme İlişkisi Söz } \\
\text { Konusudur }\end{array}$ \\
\hline $\begin{array}{l}\text { Engsted } \\
(1996)\end{array}$ & VAR Analizi & $\begin{array}{l}1948- \\
1989\end{array}$ & Danimarka & $\begin{array}{l}\text { Enflasyonun Faiz Oranı Üzerinde Pozitif Yönlü Etkisi Vardır, } \\
\text { Değişkenler Arasında Eşbütünleşme İlişkisi Söz Konusudur }\end{array}$ \\
\hline $\begin{array}{l}\text { Crowder } \\
(1997)\end{array}$ & $\begin{array}{c}\text { Johansen } \\
\text { Eşbütünleşme } \\
\text { Analizi }\end{array}$ & $\begin{array}{l}1960- \\
1991\end{array}$ & Kanada & Değişkenler Arasında Eşbütünleşme İliş̧kisi Söz Konusudur \\
\hline $\begin{array}{l}\text { Junttila } \\
(2001)\end{array}$ & $\begin{array}{c}\text { Johansen } \\
\text { Eşbütünleşme } \\
\text { Analizi }\end{array}$ & $\begin{array}{l}1987: 01 \\
1996: 12\end{array}$ & Finlandiya & Değişkenler Arasında Eşbütünleşme İlişkisi Söz Konusudur \\
\hline
\end{tabular}


Akıncı, M. \& Ö. Yılmaz (2016), "Enflasyon-Faiz Oranı Takası: Fisher Hipotezi Bağlamında Türkiye Ekonomisi İçin Dinamik En Küçük Kareler Yöntemi”, Sosyoekonomi, Vol. 24(27), 33-55.

\begin{tabular}{|c|c|c|c|c|}
\hline $\begin{array}{l}\text { Atkins \& } \\
\text { Coe }(2002)\end{array}$ & $\begin{array}{l}\text { ARDL Sinir } \\
\text { Testi Analizi }\end{array}$ & $\begin{array}{l}1953: 01 \\
1999: 12\end{array}$ & $\begin{array}{l}\text { ABD, } \\
\text { Kanada }\end{array}$ & $\begin{array}{l}\text { Enflasyonun Faiz Oranı Üzerinde Pozitif Yönlü Etkisi Vardır, } \\
\text { Değiskenler Arasında Eşbütünlessme İliskisi Söz Konusudur }\end{array}$ \\
\hline $\begin{array}{l}\text { Choi } \\
(2002)\end{array}$ & $\begin{array}{c}\text { Zaman Serisi } \\
\text { Analizi }\end{array}$ & $\begin{array}{l}1947: 01 \\
1997: 12\end{array}$ & $\mathrm{ABD}$ & Enflasyonun Faiz Oranı Üzerinde Pozitif Yönlü Etkisi Vardır \\
\hline $\begin{array}{l}\text { Carneiro } \\
\text { vd. } \\
(2002)\end{array}$ & $\begin{array}{c}\text { Johansen } \\
\text { Eşbütünleşme } \\
\text { Analizi }\end{array}$ & $\begin{array}{l}1980: 01- \\
1997: 12\end{array}$ & $\begin{array}{l}\text { Arjantin, } \\
\text { Brezilya, } \\
\text { Meksika }\end{array}$ & Değişkenler Arasında Eşbütünleşme İlişkisi Söz Konusudur \\
\hline $\begin{array}{l}\text { Berument } \\
\& \\
\text { Jelassi } \\
(2002)\end{array}$ & $\begin{array}{l}\text { Zaman Serisi } \\
\text { Analizi }\end{array}$ & $\begin{array}{l}1957: 04 \\
1998: 05\end{array}$ & 26 Ülke & Enflasyonun Faiz Oranı Üzerinde Pozitif Yönlü Etkisi Vardır \\
\hline $\begin{array}{l}\text { Lardic \& } \\
\text { Mignon } \\
(2003)\end{array}$ & $\begin{array}{l}\text { Zaman Serisi } \\
\text { Analizi }\end{array}$ & $\begin{array}{l}\text { 1970:Q1 } \\
\text { 2001:Q3 }\end{array}$ & G7 Ülkeleri & $\begin{array}{l}\text { Değişkenler Arasında Eşbütünleşme İlişkisi Söz Konusudur, } \\
\text { Enflasyonun Faiz Oranı Üzerinde Pozitif Yönlü Etkisi Vardır }\end{array}$ \\
\hline $\begin{array}{l}\text { Wong \& } \\
\text { Wu }(2003)\end{array}$ & $\begin{array}{l}\text { Araç } \\
\text { Değişkenli } \\
\text { Regresyon } \\
\text { Yöntemi }\end{array}$ & $\begin{array}{l}\text { 1958:01 } \\
\text { 1999:04 }\end{array}$ & $\begin{array}{c}\text { G7 Ülkeleri, } \\
\text { Misır, Asya } \\
\text { Ülkeleri }\end{array}$ & Enflasyonun Faiz Oranı Üzerinde Pozitif Yönlü Etkisi Vardır \\
\hline $\begin{array}{l}\text { Kutan \& } \\
\text { Aksoy } \\
(2003)\end{array}$ & GARCH & $\begin{array}{l}1986: 12 \\
2001: 03\end{array}$ & Türkiye & Enflasyonun Faiz Oranı Üzerinde Pozitif Yönlü Etkisi Vardır \\
\hline $\begin{array}{l}\text { Turgutlu } \\
(2004)\end{array}$ & ARFIMA & $\begin{array}{l}\text { 1978:Q4 } \\
\text { 2003:Q4 }\end{array}$ & Türkiye & Değişkenler Arasında Eşbütünleşme İlişkisi Söz Konusudur \\
\hline $\begin{array}{l}\text { Sun \& } \\
\text { Phillips } \\
(2004)\end{array}$ & $\begin{array}{l}\text { Zaman Serisi } \\
\text { Analizi }\end{array}$ & $\begin{array}{l}\text { 1934:Q1 } \\
\text { 1999:Q4 }\end{array}$ & $\mathrm{ABD}$ & Enflasyonun Faiz Oranı Üzerinde Pozitif Yönlü Etkisi Vardır \\
\hline $\begin{array}{l}\text { Million } \\
(2004)\end{array}$ & $\begin{array}{c}\text { Eşik } \\
\text { Otoregresif } \\
\text { Analiz }\end{array}$ & $\begin{array}{l}1951: 01 \\
1999: 12\end{array}$ & $\mathrm{ABD}$ & $\begin{array}{l}\text { Değişkenler Arasında Eşbütünleşme İlişkisi Söz Konusudur, } \\
\text { Enflasyonun Faiz Oranı Üzerinde Pozitif Yönlü Etkisi Vardır }\end{array}$ \\
\hline $\begin{array}{l}\text { Atkins \& } \\
\text { Chan } \\
(2004)\end{array}$ & $\begin{array}{l}\text { ARDL Sınır } \\
\text { Testi Analizi }\end{array}$ & $\begin{array}{l}\text { 1950:Q1 } \\
\text { 2000:Q2 }\end{array}$ & $\begin{array}{l}\text { ABD, } \\
\text { Kanada }\end{array}$ & $\begin{array}{l}\text { Değişkenler Arasında Eşbütünleşme İlişkisi Söz Konusudur, } \\
\text { Enflasyonun Faiz Oranı Üzerinde Pozitif Yönlü Etkisi Vardır }\end{array}$ \\
\hline $\begin{array}{l}\text { Madsen } \\
(2005)\end{array}$ & $\begin{array}{l}\text { Panel Veri } \\
\text { Analizi }\end{array}$ & $\begin{array}{c}1958- \\
1999\end{array}$ & $\begin{array}{l}16 \text { OECD } \\
\text { Ülkesi }\end{array}$ & Enflasyonun Faiz Oranı Üzerinde Pozitif Yönlü Etkisi Vardır \\
\hline $\begin{array}{l}\text { Şimşek \& } \\
\text { Kadilar } \\
(2006)\end{array}$ & $\begin{array}{l}\text { ARDL Sınır } \\
\text { Testi Analizi }\end{array}$ & $\begin{array}{l}\text { 1987:Q1 } \\
\text { 2004:Q4 }\end{array}$ & Türkiye & $\begin{array}{l}\text { Değişkenler Arasında Eşbütünleşme İlişkisi Söz Konusudur, } \\
\text { Enflasyonun Faiz Oranı Üzerinde Pozitif Yönlü Etkisi Vardır }\end{array}$ \\
\hline $\begin{array}{l}\text { Herwartz } \\
\& \\
\text { Reimers } \\
(2006)\end{array}$ & $\begin{array}{l}\text { Panel Veri } \\
\text { Analizi }\end{array}$ & $\begin{array}{l}\text { 1960:01 } \\
\text { 2004:06 }\end{array}$ & 100 Ülke & Enflasyonun Faiz Oranı Üzerinde Pozitif Yönlü Etkisi Vardır \\
\hline $\begin{array}{l}\text { Kasman } \\
\text { vd. } \\
(2006)\end{array}$ & ARFIMA & $\begin{array}{l}\text { 1957:01 } \\
\text { 2004:07 }\end{array}$ & $\begin{array}{l}33 \text { Gelişmiş } \\
\text { ve } \\
\text { Gelişmekte } \\
\text { Olan Ülke }\end{array}$ & Değişkenler Arasında Eşbütünleşme İlişkisi Söz Konusudur \\
\hline $\begin{array}{l}\text { Berument } \\
\text { vd. } \\
(2007)\end{array}$ & $\begin{array}{l}\text { ARCH- } \\
\text { GARCH }\end{array}$ & $\begin{array}{l}\text { 1957:01 } \\
\text { 2004:08 }\end{array}$ & $\begin{array}{l}\text { G7 ve } 45 \\
\text { Gelişmekte } \\
\text { Olan Ülke }\end{array}$ & Enflasyonun Faiz Oranı Üzerinde Pozitif Yönlü Etkisi Vardır \\
\hline $\begin{array}{l}\text { Beyer vd. } \\
(2009)\end{array}$ & $\begin{array}{c}\text { Johansen } \\
\text { Eşbütünleşme } \\
\text { Analizi, } \\
\text { Dinamik EKK }\end{array}$ & $\begin{array}{l}\text { 1957:Q1 } \\
\text { 2007:Q4 }\end{array}$ & $\begin{array}{l}15 \text { Gelişmiş } \\
\text { Ülke }\end{array}$ & $\begin{array}{l}\text { Enflasyonun Faiz Oranı Üzerinde Pozitif Yönlü Etkisi Vardır, } \\
\text { Değişkenler Arasında Eşbütünleşme İlişkisi Söz Konusudur }\end{array}$ \\
\hline \multicolumn{5}{|c|}{ Fisher Hipotezinin Geçersiz Olduğunu Gösteren Çalışmalar } \\
\hline $\begin{array}{l}\text { Jaffe \& } \\
\text { Mandelker } \\
(1976)\end{array}$ & $\begin{array}{l}\text { Zaman Serisi } \\
\text { Analizi }\end{array}$ & $\begin{array}{l}1875- \\
1970\end{array}$ & $\mathrm{ABD}$ & Enflasyon $\succ$ Faiz \\
\hline $\begin{array}{l}\text { Summers } \\
(1982)\end{array}$ & $\begin{array}{l}\text { Zaman Serisi } \\
\text { Analizi }\end{array}$ & $\begin{array}{c}1860- \\
1971\end{array}$ & $\mathrm{ABD}$ & Enflasyonun Faiz Oranı Üzerinde Anlamlı Bir Etkisi Yoktur \\
\hline $\begin{array}{l}\text { Kane vd. } \\
(1983)\end{array}$ & $\begin{array}{l}\text { Zaman Serisi } \\
\text { Analizi }\end{array}$ & $\begin{array}{l}1974: 01 \\
1979: 12\end{array}$ & $\begin{array}{l}6 \text { Gelişmiş } \\
\text { Ülke }\end{array}$ & $\begin{array}{l}\text { Enflasyon } \prec \text { Faiz, Enflasyonun Faiz Oranı Üzerinde Anlamlı Bir } \\
\text { Etkisi Yoktur }\end{array}$ \\
\hline Gültekin & ARIMA & 2. Dünya & 26 Ülke & Enflasyonun Faiz Oranı Üzerinde Anlamlı Bir Etkisi Yoktur \\
\hline
\end{tabular}


Akınc1, M. \& Ö. Yılmaz (2016), "Enflasyon-Faiz Oranı Takası: Fisher Hipotezi Bağlamında

Türkiye Ekonomisi İçin Dinamik En Küçük Kareler Yöntemi”, Sosyoekonomi, Vol. 24(27), 33-55.

\begin{tabular}{|c|c|c|c|c|}
\hline$(1983)$ & & $\begin{array}{l}\text { Savaş1 } \\
\text { Sonras1 }\end{array}$ & & \\
\hline $\begin{array}{l}\text { Graham } \\
(1988)\end{array}$ & $\begin{array}{l}\text { Zaman Serisi } \\
\text { Analizi }\end{array}$ & $\begin{array}{c}1953- \\
1978\end{array}$ & $\mathrm{ABD}$ & Enflasyonun Faiz Oranı Üzerinde Anlamlı Bir Etkisi Yoktur \\
\hline $\begin{array}{l}\text { Mishkin } \\
(1993)\end{array}$ & $\begin{array}{l}\text { Zaman Serisi } \\
\text { Analizi }\end{array}$ & $\begin{array}{l}1964: 02 \\
1986: 12\end{array}$ & $\mathrm{ABD}$ & $\begin{array}{l}\text { Kısa Dönemde Enflasyonun Faiz Oranı Üzerinde Anlamlı Bir } \\
\text { Etkisinin Olmadığı, Ancak Uzun Dönemde Enflasyonun Faiz } \\
\text { Oranlarını Etkileyebileceği Sonucu Geçerlidir }\end{array}$ \\
\hline $\begin{array}{l}\text { Inder \& } \\
\text { Silvapulle } \\
(1993)\end{array}$ & $\begin{array}{l}\text { Vektör Hata } \\
\text { Düzeltme } \\
\text { Modeli }\end{array}$ & $\begin{array}{c}1965- \\
1990\end{array}$ & Avustralya & Değişkenler Arasında Eşbütünleşme İlişkisi Söz Konusu Değildir \\
\hline $\begin{array}{l}\text { Dutt \& } \\
\text { Ghosh } \\
(1995)\end{array}$ & $\begin{array}{l}\text { Johansen } \\
\text { Eşbütünleşme } \\
\text { Analizi, } \\
\text { FM-EKK }\end{array}$ & $\begin{array}{l}1960- \\
1993\end{array}$ & Kanada & $\begin{array}{l}\text { Değişkenler Arasında Eşbütünleşme İlişkisi Söz Konusu Değildir, } \\
\text { Enflasyonun Faiz Oranı Üzerinde Anlamlı Bir Etkisi Yoktur }\end{array}$ \\
\hline $\begin{array}{l}\text { Linden } \\
(1995)\end{array}$ & $\begin{array}{l}\text { Johansen } \\
\text { Eşbütünleşme } \\
\text { Analizi }\end{array}$ & $\begin{array}{l}1987: 01 \\
1995: 03\end{array}$ & Finlandiya & Enflasyonun Faiz Oranı Üzerinde Etkisi Anlamsızıdır \\
\hline $\begin{array}{l}\text { Coppock \& } \\
\text { Poitras } \\
(2000)\end{array}$ & $\begin{array}{l}\text { Yatay Kesit } \\
\text { Analizi }\end{array}$ & $\begin{array}{c}1976- \\
1988\end{array}$ & 40 Ülke & Enflasyonun Faiz Oranı Üzerinde Anlamlı Bir Etkisi Yoktur \\
\hline $\begin{array}{l}\text { Çakmak } \\
\text { vd. } \\
(2002)\end{array}$ & VAR & $\begin{array}{l}\text { 1989:01 } \\
\text { 2001:07 }\end{array}$ & Türkiye & $\begin{array}{l}\text { Enflasyonun Faiz Oranları Üzerinde Bir Etkisi Yoktur, Faiz } \\
\text { Oranlarının Enflasyon Üzerindeki Etkisi İse Zayıftır }\end{array}$ \\
\hline $\begin{array}{l}\text { Gül \& } \\
\text { Açıkalın } \\
(2008)\end{array}$ & $\begin{array}{l}\text { Johansen } \\
\text { Eşbütünleşme } \\
\text { Analizi }\end{array}$ & $\begin{array}{l}\text { 1990:01 } \\
\text { 2003:12 }\end{array}$ & Türkiye & Değişkenler Arasında Eşbütünleşme İlişkisi Söz Konusu Değildir \\
\hline $\begin{array}{l}\text { Y1lanc1 } \\
(2009)\end{array}$ & $\begin{array}{l}\text { Engle- } \\
\text { Granger } \\
\text { Eşbütünleşme } \\
\text { Modeli }\end{array}$ & $\begin{array}{l}\text { 1989:Q1 } \\
\text { 2008:Q1 }\end{array}$ & Türkiye & Değişkenler Arasında Eşbütünleşme İlişkisi Söz Konusu Değildir \\
\hline $\begin{array}{l}\text { Ito } \\
(2009)\end{array}$ & $\begin{array}{l}\text { Zaman Serisi } \\
\text { Analizi }\end{array}$ & $\begin{array}{l}1987: 01 \\
2006: 06\end{array}$ & Japonya & $\begin{array}{l}\text { Fisher Etkisi Sadece 1987:10-1991:06 Dönemi Için Geçerlidir, } \\
\text { Değişkenler Arasında Eşbütünleşik İlişkiler Söz Konusudur ve } \\
\text { Enflasyon Faiz Oranını Etkilemektedir. Ancak Hipotez 1987:10- } \\
\text { 2006:06 Dönemi İçin Geçerli Değildir, Eşbütünleşik İlişkiler Yoktur } \\
\text { ve Enflasyon Faiz Oranın Etkilememektedir. }\end{array}$ \\
\hline
\end{tabular}

\section{Yöntem ve Veriler}

Bu çalışmada, enflasyon ve faiz oranı arasındaki ilişkiler Fisher Hipotezinin birebir etkileşim süreci kapsamında Türkiye ekonomisi için 1980-2012 dönemi yıllık verileri itibariyle DOLS analizi yardımıyla incelenmiştir. Oluşturulan temel modeller için kullanılacak değişkenler, Fisher Hipotezinin öngördüğü şekilde seçilmiş ve enflasyon-faiz oranı arasındaki ilişkilere doğrudan etki edebileceği düşünülen değişkenler de ifade edilen minvalde modellere dâhil edilmiştir. Ayrıca, ifade edilen değişkenler arasındaki ilişkileri dinamik olarak inceleyebilmek amacıyla çeşitli kontrol değişkenleri de oluşturulan modellere ilave edilmiş ve böylece daha sağlam (robust) sonuçlar elde edilmeye çalışılmıştır. Diğer taraftan, gerek ulusal ve gerekse uluslararası literatürde konu ile ilgili olarak yapılan çalışmalarda enflasyon oranının temel göstergesi olarak tüketici fiyat endeksi bazında enflasyon değerleri ve faiz oranın temel göstergesi olarak da mevduatlara uygulanan nominal faizler kullanıldığından dolayı, bu çalışmada da ilgili göstergeler dikkate alınmıştır. Çalışmanın sağlamlılığını sınamak üzere kullanılan ilave değişkenler ise, enflasyon-faiz oranı ilişkisine en fazla etki edebileceğini düşündüğümüz ve bir kısmı yine uygulamalı 
çalışmalarda yer alan değişkenlerden seçilmiştir. Çalışmaya konu olan değişskenler ile ilgili tanımsal bilgiler Tablo 2'de sunulmuştur.

\section{Değişkenler İle İlgili Tanımsal Bilgiler}

\begin{tabular}{|c|c|c|c|c|}
\hline Veri Tanımı & Kisaltma & Veri Kapsamı & Birim & Kaynak \\
\hline Faiz Oranı & IR & $\begin{array}{l}\text { Ticari veya Benzeri Bankalar Tarafindan Mevduatlara } \\
\text { Uygulanan Yıllık Faiz Oranı }\end{array}$ & $\%$ & $\begin{array}{l}\text { World Bank - World } \\
\text { Development Indicator } \\
\text { (WDI) }\end{array}$ \\
\hline $\begin{array}{l}\text { Enflasyon } \\
\text { Oranı }\end{array}$ & INF & Tüketici Fiyatları İtibariyle Y1llık Enflasyon Oranı & $\%$ & World Bank - WDI \\
\hline Cari Denge & $\mathrm{CAB}$ & $\begin{array}{l}\text { Gayri Safi Yurtiçi Hasıla'nın Bir Yüzdesi Olarak Cari Açık } \\
\text { veya Cari Fazla }\end{array}$ & $\%$ & World Bank - WDI \\
\hline $\begin{array}{l}\text { Dış Borç } \\
\text { Servisi }\end{array}$ & EDS & $\begin{array}{l}\text { Diş Borçların Para, Mal veya Hizmetler Kanalıyla } \\
\text { Ödenebilirlik Yeteneği }\end{array}$ & $\begin{array}{l}\text { USD } \\
\$\end{array}$ & World Bank - WDI \\
\hline $\begin{array}{l}\text { Gayri Safi } \\
\text { Yurtiçi } \\
\text { Tasarruf }\end{array}$ & GDS & $\begin{array}{l}\text { Gayri Safi Yurtiçi Hasıla'nın Bir Yüzdesi Olarak Gayri Safi } \\
\text { Yurtiçi Hasıla'dan Nihai Tüketim Harcamalarının Çıkarılması } \\
\text { Sonucu Elde Edilen Tasarruf Tutarı }\end{array}$ & $\%$ & World Bank - WDI \\
\hline Para Arz1 & $\mathrm{BM}$ & $\begin{array}{l}\text { Gayri Safi Yurtiçi Hasıla'nın Bir Yüzdesi Olarak M2 Tanımı } \\
\text { Dâhilindeki Para Arzı }\end{array}$ & $\%$ & World Bank - WDI \\
\hline Döviz Kuru & ER & TL ile USD Doları Arasındaki Parite Kuru & $\mathrm{TL} / \$$ & $\begin{array}{l}\text { Türkiye Cumhuriyet } \\
\text { Merkez Bankas1 - EVDS }\end{array}$ \\
\hline $\begin{array}{l}\text { Ekonomik } \\
\text { Büyüme }\end{array}$ & PCGDP & $\begin{array}{l}\text { Kişi Başına Düşen Gayri Safi Yurtiçi Hasıla'daki Yıllık } \\
\text { Büyüme Hızı }\end{array}$ & $\%$ & World Bank - WDI \\
\hline
\end{tabular}

Çalışmada öncelikle değişkenlerin zaman serisi özellikleri incelenmiştir. Çünkü zaman serisi özellikleri incelenmeden tahmin edilen bir model Granger ve Newbold (1974)'un ifade ettiği gibi, gerçekte olmayan ilişkilerin varmış gibi görünmesi olarak ifade edilen sahte regresyonlara neden olabilmektedir. Bu nedenle, model çözümlemelerinde kullanılacak olan değişkenlerin durağan olup olmadıkları ve eğer durağan iseler hangi seviyede durağan oldukları Dickey-Fuller $(1979,1981)$ tarafından geliştirilen ADF birim kök testi ile belirlenmiştir.

Değişkenlerin durağanlıkları araştırıldıktan sonra sıra eşbütünleşme analizine gelmektedir. Eşbütünleşme analizi, iktisadi değişkenlere ait seriler durağan olmasalar bile, bu serilerin durağan bir doğrusal kombinasyonunun olabileceğini, bunun ekonometrik olarak belirlenebileceğini ve dolayısıyla değişkenler arasında uzun dönemli bir ilişkinin varlığını ortaya koyabilmektedir. Bu bağlamda, iki zaman serisi aynı dereceden entegre iseler, bu durumda iki seri arasında bir eşbütünleşme olabilir ve aralarındaki regresyon yanıltıcı olmaz (Tarı, 2005: 405-406). Değişkenler arasındaki eşbütünleşme analizinin test edilebilmesi için analize tabi tutulan her değişkenin en az birinci dereceden bütünleşik olmaları ve aynı zamanda değişkenlerin bütünleşme derecelerinin de eşit olması gerekmektedir (Enders, 1995: 396). Johansen (1988, 1991, 1995) ve Johansen-Juselius (1990) eşbütünleşme testi, aşağıdaki (7) numaralı regresyon dikkate alınarak yapılmaktadır:

$$
\Delta x_{t}=\alpha\left(\beta^{\prime} x_{t-1}-\beta_{0}-\beta_{1 t}\right)-\gamma_{0}-\gamma_{1 t}+\sum_{j=1}^{k} \Gamma_{j} \Delta x_{t-j}+\varepsilon_{t}
$$


Burada $x_{t}, t$ döneminde gözlenen değişkenlerin $p x l$ vektörünü; $\boldsymbol{\alpha}$ terimi, $p x r$ katsayılar matrisini; $\beta, r$ eşbütünleşik vektörlerini tanımlayan $p x r$ katsayılar matrisini; $\beta_{0}$ , eşbütünleşik vektörler için kesikli $r x 1$ vektörünü; $\beta_{1}$, eşbütünleşik vektörlerde lineer deterministik trendlerine olanak tanıyan $r x l$ katsayılar vektörünü; $\gamma_{0}$, denklemdeki $p x l$ kesikli vektörünü; $\gamma_{1}, p x l$ lineer trend katsayılar vektörünü ve $\Gamma_{j}, \mathrm{j}=1 \ldots$ k’ya kadar olan ve gecikme uzunluğunu tanımlayan $\operatorname{pxp}$ matrislerini ifade etmektedir.

Eşbütünleşme analizinden sonra değişkenler arasında bir sebep-sonuç ilişkisi olup olmadığı nedensellik analizi ile araştırılmıştır. Granger nedenselliğinde $X$ ve $Y$ gibi iki değişken arasındaki ilişkinin yönü araştırılır. Eğer mevcut $Y$ değeri, $X$ değişkenin şimdiki değerinden çok, geçmiş dönem değerleri ile daha iyi tahmin edilebiliyorsa, $X$ değişkeninden $Y$ değişkenine doğru bir Granger nedenselliğinden söz edilebilir (Charemza \& Deadman, 1993: 190). Bununla birlikte, modelde dikkate alınan değişkenler arasında eşbütünleşik ilişkiler elde edilirse, Vektör Hata Düzeltme Modeli (VECM) kapsamında eşbütünleşme analizinden elde edilen hata terimleri de nedensellik modeline ilave edilir. Genel bir formda belirtmek gerekirse, iki değiş̧ken arasındaki eşbütünleşme ilişkisi (8) ve (9) numaralı kalıplar yardımılla incelenmektedir:

$$
\begin{aligned}
& Y_{t}=\sum_{i=1}^{n} \alpha_{i} Y_{t-i}+\sum_{i=1}^{n} \beta_{i} X_{t-i}+\varepsilon_{1 t} E C_{r, t-1}+u_{1 t} \\
& X_{t}=\sum_{i=1}^{n} \gamma_{i} X_{t-i}+\sum_{i=1}^{n} \varsigma_{i} Y_{t-i}+\varepsilon_{2 t} E C_{r, t-1}+u_{2 t}
\end{aligned}
$$

Burada $u_{1 t}$ ve $u_{2 t}$ hata terimlerinin ilişkisiz oldukları varsayılmaktadır. Böylece, (8) ve (9) numaralı denklemler değişkenlerin geçmiş değerlerine bağlı olduğu kadar, kendi geçmiş değerlerinin de bir fonksiyonudur. Granger nedenselliğinde $Y_{t}$ ile $X_{t}$ arasında tek ve çift yönlü bir nedensellik ilişkisi olabileceği gibi, değişkenler arasında herhangi bir nedensellik ilişkisinin söz konusu olmadığ 1 durum da ortaya çıkabilir.

Uzun dönem katsayılarının tahmin edilmesinde kullanılan Johansen-Juselius prosedürünün yanı sıra, daha etkin ve daha sağlam (robust) uzun dönem katsayılarına ulaşma imkânı tanıyan bir diğer yöntem Phillips ve Loretan (1991), Saikkonen (1991) ve Stock ve Watson (1993) tarafından literatüre kazandırılan DOLS analizidir. Bu analiz yardımıyla uzun dönem denge tahminlerine ilaveten regresörler arasındaki olası eşanlılık eğilimleri de ortaya konmaktadır. DOLS analizi, Masih ve Masih (1996) tarafindan da vurgulandığ üzere, 
model içinde dikkate alınan değişkenlerin farklı derecelerde entegre, ancak hala eşbütünleşik olabildiği uzun dönem denge tahminine yönelik bir parametrik yaklaşımdır. Regresörler arasındaki potansiyel eşanlılık eğilimi, modelde dikkate alınan değişkenlerin gecikmeli, fark ve sonraki dönem değerlerindeki değişimin sisteme dâhil edilmesiyle izlenebilmektedir. Diğer bir deyişle, DOLS analizinde değişkenlerin hepsinin $I(d)$ ve tek bir eşbütünleşme ilişkisinin söz konusu olduğunun varsayıldığı durumda; bağımlı değişkenin, diğer değişkenlerin farklarının gecikmeli ve öncül değerleri üzerine regresyonu yapılarak parametre tahminleri elde edilmektedir (Çetin \& Seker, 2012: 97). Bu bağlamda DOLS analizi, gecikmeli ve sonraki dönem değerli $\Delta X_{t}$ gibi bir regresöre dayanmakta ve (10) numaralı genişletilmiş eşbütünleşik regresyon denklemi yardımıyla ifade edilmektedir.

$$
y_{t}=X_{t}^{\prime} \beta+D_{t}^{\prime} \gamma+\sum_{j=-q}^{r} \Delta X_{t+j}^{\prime} \delta+v_{t}
$$

(10) numaralı denklemde yer alan $y_{t}$, bağımlı değişkeni; $X^{\prime}$, açıklayıcı değişkenler matrisini; $q$, gecikme düzeyini; $r$, sonraki dönem değerini; $\Delta$, fark operatörünü; $D_{t}^{\prime}$, modele etki edebilecek olan ilave değişkenleri $\beta$ ve $\gamma$, EKK yöntemi ile tahmin edilecek olan eşbütünleşme vektörlerini ve $v_{t}$ ise beyaz gürültü hata terimini ifade etmektedir. Tahmin edilen (10) numaralı eşitlik yardımıyla DOLS bulguları elde edilmektedir. Bu bağlamda, DOLS analizi için çözümleme sürecine konu olan temel model,

$$
\begin{aligned}
\Delta I R_{t}= & \beta_{0}+\beta_{1} \Delta I N F_{t}+\beta_{2} \Delta I N F_{t-i}+\left(\beta_{3} \Delta C A B_{t}+\beta_{4} \Delta C A B_{t-i}\right. \\
& +\beta_{5} \Delta E D S_{t}+\beta_{6} \Delta E D S_{t-i}+\beta_{7} \Delta G D S_{t}+\beta_{8} \Delta G D S_{t-i} \\
& +\beta_{9} \Delta B M_{t}+\beta_{10} \Delta B M_{t-i}+\beta_{11} \Delta E R_{t}+\beta_{12} \Delta E R_{t-i} \\
& \left.+\beta_{13} \Delta P C G D P+\beta_{14} \Delta P C G D P_{t-i}\right)+\beta_{15} E C_{t-1}+u_{t}
\end{aligned}
$$

olarak belirlenmiştir.

\section{Uygulama Bulguları}

Zaman serisi analizleri, değişkenlerin durağan olup olmadıklarının araştırıldığ birim kök testleri ile başlamaktadır. Tablo 3, ADF birim kök testi sonuçlarını göstermektedir. Değişkenlerin tamamının sabit, sabitli-trendli ve sabitsiz-trendsiz ADF testine tabi tutulduğu dikkate alındığında, bütün değişkenlerin birinci fark düzeylerinde durağan olduğu görülmektedir. 
Tablo: 3

\section{ADF Birim Kök Testi Sonuçları}

\begin{tabular}{|c|c|c|c|c|c|c|}
\hline \multirow{2}{*}{ Değişken } & \multicolumn{2}{|c|}{ Sabitli } & \multicolumn{2}{|c|}{ Sabitli \& Trendli } & \multicolumn{2}{|c|}{ Sabitsiz \& Trendsiz } \\
\hline & Seviye & Birinci Fark & Seviye & Birinci Fark & Seviye & Birinci Fark \\
\hline IR & $-1.716(0)$ & $-6.965(0)^{* * *}$ & $-1.827(1)$ & $-7.544(0)^{* * *}$ & $-0.630(0)$ & $-7.085(0)^{* * * *}$ \\
\hline INF & $-2.207(0)$ & $-7.647(0)^{* * * *}$ & $-2.262(0)$ & $-7.580(0)^{* * *}$ & $-2.036(0)^{* *}$ & $-7.820(0)^{* * * *}$ \\
\hline CAB & $-2.454(0)$ & $-6.827(1)^{* * * *}$ & $-3.650(0)^{* * *}$ & $-7.197(1)^{* * *}$ & $0.582(2)$ & $-6.777(1)^{* * * *}$ \\
\hline EDS & $0.838(0)$ & $-4.008(0)^{* * * *}$ & $-1.462(0)$ & $-4.136(0)^{* *}$ & $2.892(0)$ & $-3.304(0)^{* * *}$ \\
\hline GDS & $-1.832(2)$ & $-3.479(2)^{* *}$ & $-2.369(1)$ & $-4.111(4)^{* * *}$ & $-0.158(2)$ & $-5.078(1)^{* * * *}$ \\
\hline $\mathbf{B M}$ & $-0.095(1)$ & $-7.982(0)^{* * *}$ & $-3.035(0)$ & $-7.939(0)^{* * * *}$ & $1.855(1)$ & $-7.392(0)^{* * *}$ \\
\hline ER & $-0.145(1)$ & $-3.432(0)^{* * *}$ & $-2.146(1)$ & $-3.539(0)^{*}$ & $0.689(1)$ & $-3.072(0)^{* * * *}$ \\
\hline PCGDP & $-6.516(0)^{* * * *}$ & $-6.681(1)^{* * *}$ & $-2.382(0)$ & $-6.553(1)^{* * * *}$ & $-0.753(0)$ & $-6.798(1)^{* * * *}$ \\
\hline & ${ }^{*}:-2.617$ & ${ }^{*}:-2.619$ & $:-3.215$ & $:-3.215$ & ${ }^{*}:-1.610$ & * $:-1.610$ \\
\hline Kritik & $* *:-2.957$ & ${ }^{* *}:-2.960$ & ${ }^{* *}:-3.562$ & ${ }^{* *}:-3.562$ & $* *:-1.951$ & $* *:-1.952$ \\
\hline Değerler & ${ }^{* * *}:-3.653$ & $* * *:-3.661$ & $*^{* * *}:-4.284$ & ${ }^{* * *}:-4.284$ & $* * *:-2.639$ & ${ }^{* * *}:-2.641$ \\
\hline
\end{tabular}

Not: Parantez içindeki değerler ilgili değişkene ait optimum gecikme uzunluklarını yansitmakta olup, bu değerler maksimum 5 gecikme uzunluğu üzerinden Schwarz Bilgi Kriteri kullanılarak elde edilmiştir. ${ }^{*},{ }^{* *}$ ve ${ }^{* * *}$ işaretleri ilgili değişkenin sirasiyla \%10, \%5 ve\%1 önem seviyesinde durağan olduğunu yansitmaktadır.

Birçok ekonometrist, standart birim kök testlerinin yapısal değişmelere maruz kalacak değişkenler için uygun olmadığını belirtmiştir. Dolayısıyla, yapısal değişmelerin söz konusu olduğu durumlarda ADF ve PP gibi temel durağanlık analizlerinin birim kök hipotezini reddedememe eğilimi içinde olacağı vurgulanmış ve bu bağlamda değişkenlerin durağan olup olmadıklarının yalnızca standart birim kök test sonuçlarına bağlı olarak karar verilmesinin yanıltıcı bulgular ortaya çıkarabileceği ifade edilmiştir. Söz konusu bu eksikliği giderebilmek amacıyla Zivot ve Andrews (1992) tarafindan geliştirilen birim kök testi (ZA), trend fonksiyonunda tahmini bir kırılmaya izin veren alternatif hipoteze dayanmaktadır. ZA testinde yapısal kırılmanın içsel olarak kabul edilmesi, bu testin diğer yapısal kırılmalı birim kök analizlerine kıyasla üstünlüğünü ortaya koymaktadır (Çil-Yavuz, 2006: 165). Üç ayrı denklem itibariyle hesaplanabilen ZA testinde, ardışı ADF test yöntemi ile örnek içindeki mümkün olan her kırılma noktası için regresyon denklemi tahmin edilmekte ve tahmin edilen parametreler için $t$ istatistiği hesaplanmaktadır. ZA testinde model A, ortalamadaki kırılmayı; model $\mathrm{B}$, eğimdeki kırılmayı ve model $\mathrm{C}$ ise yapısal bir değişimin hem ortalama ve hem de eğimi değiştiren bir kırılmayı vurgulayan denklemi ifade etmektedir. Ancak ilgili üç modelin hangisinin daha üstün olduğu konusunda fikir birliği olmaması nedeniyle genellikle A ve C modelleri kullanılmaktadır. Temel olarak bu analiz yöntemi, modelde dikkate alınan değişkenlerin ilgili zaman döneminde bir yapısal değişimden kaynaklanan kırılmaya maruz kalıp kalmadığını ölçtüğünden dolayı, Fisher hipotezinin temelini oluşturan enflasyon ve faiz oranı değişkenleri itibariyle yapısal kırılmaların söz konusu olup olmadığının incelenebilmesi amacıyla ZA analizi yapılmış ve sonuçlar Tablo 4'de gösterilmiştir. 
Tablo: 4

\section{ZA Birim Kök Testi Sonuçları}

\begin{tabular}{|c|c|c|c|c|}
\hline \multirow{2}{*}{ Değişken } & \multicolumn{2}{|c|}{ Model A } & \multicolumn{2}{|c|}{ Model C } \\
\hline & Minimum Test İstatistiği & Kırılma Tarihi & Minimum Test İstatistiği & Kırılma Tarihi \\
\hline INF & $1.364(1)$ & 2000 & $-5.046(1)^{* *}$ & 2000 \\
\hline IR & $-3.394(3)$ & 2001 & $-6.010(2)^{* * *}$ & 2001 \\
\hline \multicolumn{5}{|c|}{ Kritik Değerler } \\
\hline$\frac{{ }^{* * * *}: \% 1}{534}$ & $\stackrel{* * * \% 5}{ }$ & $\stackrel{*}{* \% 10}$ & $\begin{array}{l}{ }^{* * * *}: \% 1 \\
557\end{array}$ & :\%10 \\
\hline
\end{tabular}

Not: Parantez içindeki değerler, maksimum 5 gecikme uzunluğu dikkate alınarak SIC'ye göre belirlenen optimum gecikme uzunluklarinı yansitmaktadir.

A modelinde INF ve IR değişkenlerine ait minimum test istatistikleri çeşitli önem düzeyindeki kritik değerlerden küçük olduklarından dolayı ilgili değişkenler için belirlenen tarihte meydana gelen kırılmayla durağan oldukları hipotezi reddedilmekte ve dolayısıyla da kırılma olmadan seride birim kökün varlığını gösteren temel hipotez kabul edilmektedir. C modelinde ise ilgili değişkenlerine ait minimum test istatistiği çeşitli önem düzeylerindeki kritik değerlerden büyük oldukları için belirlenen tarihte meydana gelen kırılmayla serinin durağan olduğunu gösteren alternatif hipotez kabul edilmektedir. Ortalama ve eğimdeki kırılmaları içselleştirdiği için C modelinin daha tutarlı sonuçlar ortaya koyduğunu söylemek mümkündür.

Tablo: 5

Çoklu İlişkileri Dikkate Alan Johansen-Juselius Eşbütünleşme Test Sonuçları

\begin{tabular}{|c|c|c|c|c|c|c|c|}
\hline \multicolumn{8}{|c|}{ Faiz Oranı ile Enflasyon Oranı Arasındaki Eşbütünleşme Test Sonuçları } \\
\hline $\begin{array}{c}\text { Sıfır } \\
\text { Hipotezi }\end{array}$ & $\begin{array}{c}\text { Alternatif } \\
\text { Hipotez }\end{array}$ & $\begin{array}{c}\dot{\mathbf{I} z} \\
\text { İstatistiği }\end{array}$ & $\begin{array}{l}\text { \%1 Kritik } \\
\text { Değer }\end{array}$ & $\begin{array}{l}\text { \%5 Kritik } \\
\text { Değer }\end{array}$ & $\begin{array}{c}\text { Maksimum Özdeğer } \\
\text { İstatistiği }\end{array}$ & $\begin{array}{l}\text { \%1 Kritik } \\
\text { Değer }\end{array}$ & $\begin{array}{l}\text { \%5 Kritik } \\
\text { Değer }\end{array}$ \\
\hline$r=0$ & $r=1$ & $54.156^{* * *}$ & 23.152 & 18.397 & $37.023^{* * * *}$ & 21.744 & 17.147 \\
\hline$r \leq 1$ & $r=2$ & $17.133^{* * *}$ & 6.634 & 3.841 & $17.133^{* * * *}$ & 6.634 & 3.841 \\
\hline \multicolumn{8}{|c|}{ Bütün Değişkenleri Dikkate Alan Eşbütünleşme Test Sonuçları } \\
\hline $\begin{array}{c}\text { Sıfır } \\
\text { Hipotezi }\end{array}$ & $\begin{array}{c}\text { Alternatif } \\
\text { Hipotez }\end{array}$ & $\begin{array}{c}\dot{\mathbf{I} z} \\
\text { İstatistiği }\end{array}$ & $\begin{array}{l}\text { \%1 Kritik } \\
\text { Değer }\end{array}$ & $\begin{array}{l}\text { \%5 Kritik } \\
\text { Değer }\end{array}$ & $\begin{array}{c}\text { Maksimum Özdeğer } \\
\text { İstatistiği }\end{array}$ & $\begin{array}{l}\text { \%1 Kritik } \\
\text { Değer }\end{array}$ & $\begin{array}{l}\text { \%5 Kritik } \\
\text { Değer }\end{array}$ \\
\hline$r=0$ & $r=1$ & $331.497^{* * * *}$ & 187.196 & 175.171 & $115.648^{* * *}$ & 62.174 & 55.728 \\
\hline$r \leq 1$ & $r=2$ & $215.8749^{* * * *}$ & 150.077 & 139.275 & $74.718^{* * * *}$ & 55.814 & 49.586 \\
\hline$r \leq 2$ & $r=3$ & $141.131^{\text {**** }}$ & 116.987 & 107.346 & $48.105^{* *}$ & 49.411 & 43.419 \\
\hline$r \leq 3$ & $r=4$ & $93.025^{* * * *}$ & 87.774 & 79.341 & 36.349 & 42.863 & 37.163 \\
\hline$r \leq 4$ & $r=5$ & $56.675^{* *}$ & 62.521 & 55.245 & $30.853^{* *}$ & 36.193 & 30.815 \\
\hline$r \leq 5$ & $r=6$ & 25.822 & 41.081 & 35.010 & 16.727 & 29.261 & 24.252 \\
\hline$r \leq 6$ & $r=7$ & 9.094 & 23.152 & 18.397 & 7.613 & 21.744 & 17.147 \\
\hline$r \leq 7$ & $r=8$ & 1.481 & 6.634 & 3.841 & 1.481 & 6.634 & 3.841 \\
\hline
\end{tabular}

Not: Uygun gecikme uzunluklarının seçiminde Schwarz Bilgi Kriterleri kullanılmış ve her bir eşbütünleşme modeli için maksimum 5 gecikme uzunluğu üzerinden optimum gecikme sayısı belirlenmiştir. ${ }^{* *}$ ve ${ }^{* * *}$ işaretleri ilgili değişkenler arasında sırasıyla \%5 ve \%1 önem seviyesinde eşbütünleşik ilişkilerin olduğunu yansıtmaktadır.

Modelde dikkate alınan değişkenler arasında uzun dönemli ilişkilerin söz konusu olup olmadığını araştırabilmek amacıyla yapılan ve çoklu ilişkileri dikkate alan Johansen- 
Juselius eşbütünleşme test sonuçları Tablo 5'de sunulmuştur. Analiz bulguları, faiz ve enflasyon oranları arasında iki, bütün değişkenler arasında ise beş eşbütünleşme vektörünün olduğunu göstermiştir. Bu sonuçlar, modelde dikkate alınan değişkenler arasında eşbütünleşik yani uzun dönemli ilişkilerin geçerli olduğunu göstermekte ve bu bağlamda ilgili değişkenler arasında en azından tek yönlü nedensellik ilişkisinin varlığ beklenmektedir.

Gerek faiz ve enflasyon oranları ve gerekse de analizler kapsamında dikkate alınan bütün değişkenler arasında uzun dönemli ilişkilerin bulunması dolayısıyla söz konusu değişkenler arasındaki nedensellik ilişkilerinin belirlenebilmesi amacıyla Granger nedensellik analizi uygulanmış ve sonuçlar Tablo 6'de gösterilmiştir.

Tablo: 6

\section{Granger Nedensellik Analiz Sonuçları}

\begin{tabular}{|c|c|c|c|}
\hline $\begin{array}{l}\text { Değişken } \\
\text { Çifti }\end{array}$ & $\begin{array}{c}\text { Nedenselliğin } \\
\text { Yönü }\end{array}$ & $\begin{array}{c}F-\text { İstatistiği } \\
(\text { Prob) }\end{array}$ & $E C_{t-1}$ \\
\hline \multicolumn{4}{|c|}{ Modelin Optimum Gecikme Uzunluğu: 2} \\
\hline$\Delta \mathrm{IR}-\Delta \mathrm{INF}$ & - & $0.097(0.907)$ & 0.114 \\
\hline$\Delta \mathrm{INF}-\Delta \mathrm{IR}$ & $\rightarrow$ & $2.714^{*}(0.085)$ & $-0.748^{* *}$ \\
\hline \multicolumn{4}{|c|}{ Modelin Optimum Gecikme Uzunluğu: 2} \\
\hline$\Delta \mathrm{IR}-\Delta \mathrm{CAB}$ & $\rightarrow$ & $2.848^{*}(0.076)$ & $-0.544^{* *}$ \\
\hline$\Delta \mathrm{CAB}-\Delta \mathrm{IR}$ & $\rightarrow$ & $2.971^{*}(0.069)$ & $-0.568^{*}$ \\
\hline \multicolumn{4}{|c|}{ Modelin Optimum Gecikme Uzunluğu: 1} \\
\hline$\Delta \mathrm{IR}-\Delta \mathrm{EDS}$ & - & $0.034(0.853)$ & -0.416 \\
\hline$\Delta$ EDS- $\Delta \mathrm{IR}$ & $\rightarrow$ & $2.639^{*}(0.078)$ & $-0.359^{* *}$ \\
\hline \multicolumn{4}{|c|}{ Modelin Optimum Gecikme Uzunluğu: 2} \\
\hline$\Delta \mathrm{IR}-\Delta \mathrm{GDS}$ & - & $0.572(0.571)$ & -0.157 \\
\hline$\Delta$ GDS- $\Delta$ IR & - & $2.205(0.131)$ & 0.342 \\
\hline \multicolumn{4}{|c|}{ Modelin Optimum Gecikme Uzunluğu: 2} \\
\hline$\Delta \mathrm{IR}-\Delta \mathrm{BM}$ & - & $0.936(0.405)$ & 0.465 \\
\hline$\Delta \mathrm{BM}-\Delta \mathrm{IR}$ & $\rightarrow$ & $4.930^{* * *}(0.015)$ & $-0.753^{* * *}$ \\
\hline \multicolumn{4}{|c|}{ Modelin Optimum Gecikme Uzunluğu: 2} \\
\hline$\Delta \mathrm{IR}-\Delta \mathrm{ER}$ & - & $1.306(0.288)$ & -0.520 \\
\hline$\Delta \mathrm{ER}-\Delta \mathrm{IR}$ & $\rightarrow$ & $3.464^{* *}(0.047)$ & $-0.854^{* * *}$ \\
\hline \multicolumn{4}{|c|}{ Modelin Optimum Gecikme Uzunluğu: 1} \\
\hline$\Delta \mathrm{IR}-\triangle \mathrm{PCGDP}$ & - & $0.786(0.382)$ & 0.553 \\
\hline$\Delta$ PCGDP- $\Delta$ IR & $\rightarrow$ & $6.021^{* *}(0.020)$ & $-0.797^{* * *}$ \\
\hline \multicolumn{4}{|c|}{ 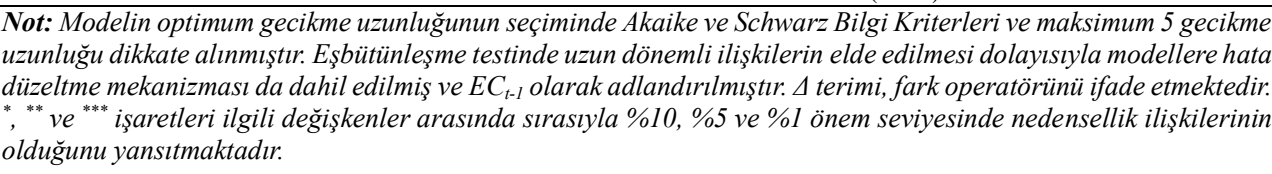 } \\
\hline
\end{tabular}

Modelde dikkate alınan değişkenler arasında uzun dönemli bir ilişki olduğundan dolayı, eşbütünleşme denklemlerinden elde edilen hata terimi nedensellik analizlerine dâhil edilmiş ve $E C$ olarak adlandırılmıştır. Granger nedensellik analiz sonuçları, Fisher Hipotezi beklentilerini karşılar nitelikte, enflasyon oranından faiz oranına doğru tek yönlü olarak sebep-sonuç ilişkilerinin geçerli olduğunu göstermiştir. Ayrıca; dış borç servisi, geniş anlamda para arzı, döviz kuru ve ekonomik büyüme değişkenlerinden faiz oranına doğru 
yine tek yönlü bir nedensellik bulgusunun olduğu ortaya konmuştur. İlaveten, analiz bulguları cari denge ile faiz oranı arasında karşılıklı nedensellik ilişkilerinin söz konusu olduğunu da yansıtmaktadır. Yurtiçi tasarruf hacminin düşük olması paralelinde yurtiçi tasarruflar ile faiz oranı arasında herhangi bir nedensellik ilişkisinin elde edilememesi ise doğal bir sonuç olarak yorumlanabilmektedir. Hâlihazırda, dış tasarruflara olan ihtiyacın ülke ekonomisi bakımından yüksek olması, bu sonucu teyit eder niteliktedir. Genel olarak değerlendirildiğinde, Türkiye ekonomisinde faiz oranlarını etkileyebilecek temel makroekonomik değişkenlerin enflasyon oranı, döviz kuru, cari denge, dış borçları ödeyebilme yeteneği, para arzındaki artış hızı ve kişi başına düşen gelirdeki değişme olduğu söylenebilir. Aralarında nedensellik ilişkisi olan değişkenlerin hata düzeltme mekanizmalarına ait olan istatistiklerin negatif ve istatistiki bakımdan anlamlı olması, ilgili değişkenlerin kendi denge değerlerine yakınsayabileceklerini ve kısa dönemde ortaya çıkabilecek olan dengesizliklerin uzun dönemde giderilebileceğini ortaya koymuştur.

Çalışmanın bu aşamasında DOLS analiz bulgularına yer verilecektir. Bu bağlamda, değişkenlerin optimum gecikmeli değerlerine ihtiyaç duyulduğundan dolay1 VAR analizi tekniğine dayanarak hazırlanan Tablo 7, değişkenlere ilişkin optimum gecikme uzunluğu sayısını yansıtmaktadır.

Tablo: 7

Optimum Gecikme Uzunlukları

\begin{tabular}{ccccccc}
\hline \multicolumn{7}{c}{ Değişkenler } \\
\hline$\Delta \mathrm{INF}$ & $\Delta \mathrm{CAB}$ & $\Delta \mathrm{EDS}$ & $\Delta$ GDS & $\Delta \mathrm{BM}$ & $\Delta \mathrm{ER}$ & $\Delta$ PCGDP \\
\hline \multicolumn{7}{c}{ Gecikme Uzunlukları } \\
\hline & 1 & 1 & 2 & 1 & 1 & 1 \\
\hline
\end{tabular}

Not: Optimum gecikme uzunluğunun seçiminde Akaike ve Schwarz Bilgi Kriterleri ve maksimum 5 gecikme uzunluğu dikkate alınmıştır. $\Delta$ terimi, fark operatörünü ifade etmektedir.

Bağımsız değişkenler ile faiz oranı arasında bir nedensellik ilişkisi olmasından dolayı hazırlanan Tablo 8, adı geçen bağımsız değişkenlerin faiz oranı üzerinde yarattı̆̆ etkilerin büyüklüğünü ve bu büyüklüklerin istatistiki bakımdan anlamlı olup olmadıklarını gösteren DOLS analiz bulgularını yansıtmaktadır. Bununla birlikte, yurtiçi tasarruf düzeyi ile faiz oranı arasında herhangi bir nedensellik ilişkisi elde edilemese bile, sadece faiz oranı üzerindeki etkisini görebilmek ve nedensellik analizini teyit edebilmek amaciyla GDS değişkeni de modelleme sürecine dâhil edilmiştir. 
Tablo: 8

DOLS Analiz Sonuçları

\begin{tabular}{|c|c|c|c|c|c|c|c|c|}
\hline \multicolumn{9}{|c|}{ Bağımlı Değişken: $\Delta \mathrm{IR}$} \\
\hline Değișken & 1 & 2 & 3 & 4 & 5 & 6 & 7 & 8 \\
\hline Sabit (C) & $-0.474(-0.425)$ & $-0.617(-0.588)$ & $-0.792(-0.448)$ & $0.030(0.026)$ & $-1.387(-1.023)$ & $0.086(0.065)$ & $-0.308(-0.298)$ & $2.488(0.952)$ \\
\hline$\Delta \mathrm{INF}$ & $0.678^{* * * * *}(3.818)$ & $0.788^{* * * *}(4.520)$ & $0.726^{* * *}(3.489)$ & $0.917^{* * * *}(4.538)$ & $0.693^{* * *}(4.041)$ & $0.530^{* *}(2.238)$ & $0.736^{* * * *}(4.285)$ & $0.507(1.190)$ \\
\hline$\Delta \mathrm{INF}(-1)$ & $0.783^{* * *}(4.485)$ & $0.849^{* * *}(5.707)$ & $0.925^{* * *}(4.282)$ & $0.974^{* * *}(5.133)$ & $0.723^{* * *}(4.425)$ & $0.793^{* * *}(3.783)$ & $0.679^{* * *}(3.979)$ & $0.658(1.713)$ \\
\hline$\Delta \mathrm{INF}(-2)$ & $0.359(1.331)$ & $0.695^{* * *}(3.039)$ & $0.311(0.750)$ & $0.508(1.667)$ & $0.402(1.506)$ & $0.160^{*}(1.810)$ & $0.580^{* *}(2.655)$ & $0.724(0.434)$ \\
\hline$\Delta \mathrm{INF}(-3)$ & $0.505(1.727)$ & $0.538^{*}(1.751)$ & $0.716(1.384)$ & $0.584(1.547)$ & 0.525 & $0.394^{*}(1.749)$ & $0.560^{* *}(2.121)$ & $-1.328(-1.682)$ \\
\hline$\Delta \mathrm{INF}(-4)$ & $0.506(1.712)$ & $0.621^{*}(1.998)$ & $0.688(1.146)$ & $0.471(1.338)$ & $0.582(1.735)$ & $0.462^{*}(2.087)$ & $0.421(1.459)$ & $0.776(0.362)$ \\
\hline$\Delta \mathrm{CAB}$ & & $3.919^{* *}(2.372)$ & & & & & & $4.469(1.049)$ \\
\hline$\Delta \mathrm{EDS}$ & & & $2.16 \mathrm{E}-10^{*}(1.793)$ & & & & & $1.29 \mathrm{E}-09(1.154)$ \\
\hline$\Delta \mathrm{EDS}(-1)$ & & & $5.95 \mathrm{E}-10(0.727)$ & & & & & $3.38 \mathrm{E}-10(0.406)$ \\
\hline$\Delta \mathrm{GDS}$ & & & & $-1.303(-0.759)$ & & & & $-1.822(-1.202)$ \\
\hline$\Delta \mathrm{GDS}(-1)$ & & & & $-0.873(-0.820)$ & & & & $-0.404(-0.945)$ \\
\hline$\Delta \mathrm{GDS}(-2)$ & & & & $0.483(0.385)$ & & & & $1.198(0.940)$ \\
\hline$\Delta \mathrm{BM}$ & & & & & $-0.771^{* *}(-2.176)$ & & & $-0.004(-0.003)$ \\
\hline$\Delta \mathrm{BM}(-1)$ & & & & & $0.298(0.439)$ & & & $0.915(0.444)$ \\
\hline$\Delta \mathrm{ER}$ & & & & & & $12.597^{*}(1.814)$ & & $-15.374(-0.771)$ \\
\hline$\Delta \mathrm{ER}(-1)$ & & & & & & $42.712^{*}(1.977)$ & & $-11.620(-1.635)$ \\
\hline $\mathrm{EC}(-1)$ & $-0.752^{* * * *}(-3.795)$ & $-0.546^{* *}(-2.159)$ & $-0.301^{*}(-1.870)$ & $-0.121^{*}(-1.859)$ & $-0.687^{* * *}(-3.114)$ & $-0.701^{* * *}(-3.583)$ & $-0.454^{* *}(-2.541)$ & $0.115(1.057)$ \\
\hline \multicolumn{9}{|c|}{ Modele İlişkin İstatistikler } \\
\hline$\overline{\mathrm{R}^{2}}$ & 0.720 & 0.702 & 0.674 & 0.526 & 0.851 & 0.778 & 0.752 & 0.320 \\
\hline$F$ (Prob) & $11.574^{* * *}(0.000)$ & $9.236^{* * *}(0.000)$ & $2.162^{* *}(0.026)$ & $1.994^{*}(0.071)$ & $7.529^{* * *}(0.000)$ & $9.282^{* * *}(0.000)$ & $7.295^{* * *}(0.000)$ & $1.069(0.897)$ \\
\hline DW & 2.202 & 2.165 & 2.218 & 1.921 & 1.944 & 2.209 & 2.110 & 1.452 \\
\hline
\end{tabular}

Not: Optimum gecikme uzunluğunun seçiminde VAR tekniği kullanılarak Akaike ve Schwarz Bilgi Kriterleri ve maksimum 5 gecikme uzunluğu dikkate alınmıştır. Parantez içindeki değerler, ilgili katsayıya ait $t$ istatistiklerini yansıtmaktadır. Eşbütünleşme testinde uzun dönemli ilişkilerin elde edilmesi dolayısılla modellere hata düzeltme mekanizması da dahil edilmiş ve EC(-1) olarak adlandırllmıştır. $\Delta$ terimi, fark operatörünü ifade etmektedir. *, ** ve *** işaretleri ilgili değişkenin sırasıly \%10, \%5 ve \%1 önem düzeyinde anlamlı olduğunu yansıtmaktadır. 
Faiz oranı üzerinde enflasyonun yarattığı etkileri doğrudan ve kontrol değişkenleri aracılığıyla dolaylı olarak görebilmek amacıyla hazırlanan Tablo 8, sekiz ayrı modelleme süreci itibariyle gerçekleştirilen DOLS analiz bulgularını yansıtmaktadır. Granger nedenselliliğini teyit eder bir yapı gösteren analiz bulguları, GDS değişkeni hariç olmak üzere, enflasyonun doğrudan ve kontrol değişkenleri aracılığıyla dolaylı olarak faiz oranı üzerinde farklı katsayı işaret ve anlamlılık düzeyleri bakımından etkisi olduğunu ortaya koymaktadır. Enflasyonun cari ve çeşitli gecikmeli değerlerinin faiz oranı üzerinde pozitif ve istatistiki bakımdan anlamlı etkiler yarattığını gösteren DOLS analiz sonuçları; cari açık, dış borç servisi, döviz kuru ve ekonomik büyüme sürecinin faiz oranını beklentileri karşılar nitelikte pozitif ve anlamlı; para arzındaki değişimin ise yine beklentiler dâhilinde negatif ve anlamlı olarak etkilediğini yansıtmaktadır. Bununla birlikte, yurtiçi tasarruf hacmindeki değişimin faiz oranı üzerindeki etkisi her ne kadar anlamsız olsa da, bu değişkenin modelleme sürecine dâhil edilmesi dolayısıyla beklenen genel eğilimin değişmediği görülmüş ve (4) numaralı modelde gösterildiği gibi enflasyon düzeyinin faiz oranını anlamlı bir şekilde pozitif yönlü olarak etkilediği gerçeği değişmemiştir. Bu bağlamda, modelleme sürecine dâhil edilen kontrol değişkenlerinin sistem üzerinde güçlendirici etkiler yarattığı söylenebilir. (1)-(7) numaralı modellerde de görüldüğü üzere, yüksek belirlilik katsayılarının varlığı, bir bütün olarak anlamlı modellerin elde edilişi ve otokorelasyon probleminin bulunmayışı ifade edilen sonuçları destekler niteliktedir. Ayrıca, modelde dikkate alınan değişkenler arasında uzun dönemli ilişkiler elde edilmesine bağlı olarak eşbütünleşme denklemlerinden elde edilen hata düzeltme mekanizması da tüm modelleme süreçlerine dâhil edilmiş ve katsayıların beklentileri karşılar nitelikte negatif ve istatistiki bakımdan anlamlı olduğu görülmüştür. $\mathrm{Bu}$ durum, kısa dönemde ortaya çıkabilecek enflasyon-faiz dengesizliklerinin uzun dönemde giderilebileceğine ilişkin önemli bir kanıt niteliği taşımaktadır. Söz konusu dengesizliklerin ortalama olarak 2.8 yıl içerisinde düzeltilebileceği gözlenmiştir. Ayrıca, gerek yüksek belirlilik katsayılarına sahip olmaları ve gerekse değişkenlerin yüksek anlamlılık değerleri itibariyle (5), (6) ve (7) numaralı modellerin en etkin modeller olduğu belirtilebilir. $\mathrm{Bu}$ modeller itibariyle; enflasyon, para arzı, döviz kuru ve ekonomik büyüme değişkenlerinin optimum seviyede bulunduğunu söylemek kuvvetle muhtemeldir. Genel olarak belirtmek gerekirse, Türkiye ekonomisinde ilgili dönem itibariyle Genelleştirilmiş Fisher Etkisi'nin geçerli olduğu söylenebilir. Diğer taraftan, bağımsız değişken olan enflasyon ile kontrol değişkenlerinin tamamının dikkate alındığı (8) numaralı modelde ise, belirtilen görüşlerin tam tersi bulgulara ulaşılmış ve genel anlamda etkin olmayan sonuçların varlığı ortaya konmuştur. Bu durum, faiz oranının kontrol edilmesinde bütün makroekonomik değişkenlerden ziyade sadece temel belirleyicilerin belirli gruplar halinde ele alınmasının zaruri olduğunu yansıtmakta ve geniş perspektif yerine daha net sonuçlara ulaşılabilecek az sayıdaki makroekonomik değişkenin dikkate alınmasının gerekliliğini vurgulamaktadır.

\section{Sonuç}

Bu çalışmada, 1980-2012 döneminde Türkiye ekonomisi için enflasyon ve faiz oranı arasındaki ilişkileri doğrudan ve çeşitli kontrol değişkenleri aracılığıyla dolaylı olarak araştırabilmek amacıyla DOLS analizinden yararlanılmıştır. 
Akınc1, M. \& Ö. Yılmaz (2016), "Enflasyon-Faiz Oranı Takası: Fisher Hipotezi Bağlamında Türkiye Ekonomisi İçin Dinamik En Küçük Kareler Yöntemi”, Sosyoekonomi, Vol. 24(27), 33-55.

Zaman serisi analizleri kapsamında ilk olarak değişkenlerin durağanlık bilgileri araştırılmış ve amaç dâhilinde gerçekleştirilen ADF birim kök testi sonuçları, bütün değişkenlerin birinci fark düzeylerinde durağan olduğunu göstermiştir. ZA yapısal kırılmalı birim kök testi ise INF ve IR değişkenlerinin belirlenen tarihte meydana gelen kırılmayla durağan olduğunu vurgulamıştır. Değişkenler arasındaki uzun dönemli ilişkiler JohansenJuselius eşbütünleşme testi ile sınanmış ve analiz bulguları, modelde dikkate alınan değişkenler arasında eşbütünleşik yani uzun dönemli ilişkilerin geçerli olduğunu ortaya koymuştur. Ayrıca, ilgili değişkenler için Granger nedensellik analizi yapılmış ve değişkenler arasında en azından tek yönlü bir nedensellik ilişkisinin geçerli olduğunu görülmüştür. DOLS analiz sonuçları, enflasyon oranı ile diğer kontrol değişkenlerinin faiz oranı üzerinde farklı katsayı işaret ve anlamlılık düzeyleri bakımından etkisi olduğunu ortaya koymuştur. Daha genel bir ifadeyle, her bir modelde enflasyon, cari açık, dış borç servisi, döviz kuru ve ekonomik büyüme sürecinin faiz oranını beklentileri karşılar nitelikte pozitif ve anlamlı; para arzındaki değişimin ise yine beklentiler dâhilinde negatif ve anlamlı olarak etkilediğini sonucuna ulaşılmıştır. Diğer taraftan, hata düzeltme mekanizması da tüm modelleme süreçlerine dâhil edilmiş ve kısa dönemde ortaya çıkabilecek enflasyon-faiz dengesizliklerinin ortalama olarak yaklaşık 2.8 yıl içinde giderilebileceğini göstermiştir. Genel olarak belirtmek gerekirse, Türkiye ekonomisinde ilgili dönem itibariyle Genelleştirilmiş Fisher Etkisi'nin geçerli olduğu söylenebilir. İlaveten analiz bulguları, genelleştirilmiş Fisher etkisinin yanı sıra, uluslararası Fisher etkisinin Türkiye ekonomisinde ilgili dönemde kendisini gösterdiği gerçeğini ortaya koymaktadır. Özellikle, enflasyon oranı ile döviz kurunun cari ve bir dönem gecikmeli değerinin faiz oranı üzerinde pozitif yönlü bir etkiye sahip olması, her üç değişkenin birbiri ile ilintili olacağı gerçeğini gözler önüne sermekte ve hem genelleştirilmiş hem de uluslararası Fisher etkisinin geçerliliğini yansıtmaktadır. Sahip olduğu etki dolayısıyla, Fisher hipotezinin varlığının sınandığ modellerde döviz kuru değişkeninin analizlere dâhil edilmesinin büyük bir önem taşıdığ vurgulanabilir.

Analize konu olan dönemde, her ne kadar şiddeti nispi olarak engellenmiş olsa da, Türkiye ekonomisinde uzun yıllar boyunca yaşanan kronik yüksek enflasyon olgusu nominal faiz oranları üzerinde bir baskı yaşanması sorununu da gündeme getirmiştir. 2001 yılına kadar uygulanan sabit kur sisteminde, söz konusu olan yüksek enflasyonu önleyebilmek için resmi döviz kurları düşük düzeylerde belirlenmiş, ancak bu kur düzeyinin sürdürülebilirlik özelliği kaybolunca devalüasyonlar kaçınılmaz bir hal almıştır. 2001 yılından sonra ise uygulanan ekonomi politikasının temeli yüksek faiz-düşük kur olarak belirlenmesine karşın, nispeten kırılgan bir ekonomik yapının varlığı özellikle son yıllarda kendini gösteren eksik değerli kur görüntüsünü ortaya çıkarmıştır. Dolayısıyla, enflasyon oranlarında yeniden iki haneli rakamlara dönülme tehlikesi, bu süreci tetikleyen önemli faktörlerden bir tanesini oluşturmuştur. $\mathrm{Bu}$ bağlamda, analize konu olan dönemde Türkiye'de faiz oranlarında meydana gelen değişmelerin enflasyondaki değişmelere paralel olarak değiştiğini söylemek mümkündür. İlaveten, Türkiye ekonomisinde değişen enflasyon ve buna bağlı olarak ortaya çıkan dalgalı faiz oranları, döviz kurlarında da aynı yönlü 
değişimlere neden olmuştur. Bununla birlikte, 2001 yılından itibaren uygulamaya konulan dezenflasyon programı; kamu kesimi mali dengesizliğinin azaltılmaya başlanması, özel sektör sabit sermaye oluşumunun hızlandırılması ve toplam faktör verimliliğinin artırılması dolayısıyla nispi bir başarı göstermiştir. Bunun yanı sıra, global ölçekte pozitif bir konjonktür dönemine erişen dünya ekonomisi dolayısıyla küresel sermayenin ülkeye yönelmesinin de önemli bir etkisi olduğu gözden kaçırılmamalıdır. Böylesi bir başarı ise enflasyonun önlenmesi hususunda önemli bir adım olarak kendini göstermiş ve faiz oranları ile döviz kurları üzerindeki baskıların dizginlenmesi sonucunu beraberinde getirmiştir. Diğer taraftan, fiyat istikrarının ve sürdürülebilirliğinin sağlanmasını temel görev olarak benimseyen TCMB, özellikle 2010 yılından itibaren kullandığı araçları çeşitlendirerek kredi ve döviz kuru mekanizmalarını da etkileyebileceği bir sistem oluşturmuştur. TCMB, 2008 Küresel Finansal Kriz sonrasında yeni bir para politikası stratejisi oluşturmuş ve esnek enflasyon hedeflemesi sistemini hayata geçirmiştir. İlgili politika süreçleri doğrultusunda politika araçlarını çeşitlendiren TCMB, politika faizi uygulamalarının yanı sıra faiz koridoru, zorunlu karşılıklar ve rezerv opsiyon mekanizmasının bir arada uygulandığı yapılanmaya yönelmiştir. Bu yapılanma, 2011 yılından itibaren finansal ve makroekonomik risklerin nispeten azalmasına yol açmış ve ekonomik istikrarın sağlanmasında başat bir rol oynamıştır. Tüm bu araçlar yardımıyla enflasyonist eğilimleri dizginlemeyi nispi olarak başaran TCMB, enflasyonun faiz oranı ve döviz kuru üzerindeki ortaya çıkarabileceği yukarı yönlü baskıların şiddetini de azaltabilmiştir.

Enflasyonun yanı sıra, faiz oranı üzerinde önemli etkiler yaratan faktörlerin cari açık, dış borç servisi, para arzı, döviz kuru ve ekonomik büyüme olduğu analiz sonuçları itibariyle belirtilebilir. Bu bağlamda, Türkiye ekonomisinde uygulanan geleneksel ve geleneksel olmayan para politikasının yanı sıra enflasyon oranları ile döviz kurları başta olmak üzere ifade edilen kontrol değişkenlerinin faiz oranını etkileyen temel belirleyiciler olduğu dikkate alınmak suretiyle ekonomi politikalarının belirlenmesi büyük bir önem taşımaktadır. Türkiye ekonomisinin geçmiş deneyimleri dikkate alındığında, ekonomi üzerindeki faiz oranı baskısının enflasyon ve adı geçen kontrol değişkenleri için yapılacak marjinal düzenlemeler itibariyle dizginlenebileceği belirtilebilir. Genel olarak ifade etmek gerekirse, Türkiye ekonomisinde değişen enflasyon oranları dolayısıyla faiz oranları pozitif yönlü olarak değişmekte, bu değişim çeşitli makroekonomik faktörler dolayısıyla güçlenmekte ve Fisher hipotezinin geçerliliğini ortaya koymaktadır.

\section{Kaynaklar}

Atkins, F.J. \& P.J. Coe (2002), “An ARDL Bounds Test of the Long-Run Fisher Effect in the United States and Canada", Journal of Macroeconomics, 24(2), 255-266.

Atkins, F.J. \& M. Chan (2004), "Trend Breaks and the Fisher Hypothesis in Canada and the United States", Applied Economics, 36(17), 1907-1913.

Barthold, T.A. \& W.R. Dougan (1986), "The Fisher Hypothesis under Different Monetary Regimes", The Review of Economics and Statistics, 68(4), 674-679.

Berument, H. \& M.M. Jelassi (2002), “The Fisher Hypothesis: A Multi-Country Analysis”, Applied Economics, 34(13), 1645-1655. 
Berument, H. \& N.B. Ceylan \& H. Olgun (2007), "Inflation Uncertainty and Interest Rates: Is the Fisher Relation Universal?", Applied Economics, 39(1), 53-68.

Beyer, A. \& A.A. Haug \& W.G. Dewald (2009), "Structural Breaks, Cointegration and the Fisher Effect”, European Central Bank Working Paper, No: 1013.

Brouwer, G. \& J. Gilbert (2005), "Monetary Policy Reaction Functions in Australia", The Economic Record, 81(253), 124-134.

Carneiro, F.G. \& J. Angelo \& C.A. Divino \& C.H. Rocha (2002), "Revisiting the Fisher Hypothesis for the Cases of Argentina, Brazil and Mexico", Applied Economics Letters, 9(2), 95-98.

Charemza, W.W. \& D.F. Deadman (1993), New Directions in Econometric Practice, UK: Edward Elgar Publishing.

Choi, W.G. (2002), "The Inverted Fisher Hypothesis: Inflation Forecastability and Asset Substitution", IMF Staff Papers, 49(2), 212-241.

Coppock, L. \& M. Poitras (2000), "Evaluating the Fisher Effect in Long-Term Cross-Country Averages", International Review of Economics \& Finance, 9(2), 181-192.

Crowder, W.J. (1997), "The Long-Run Fisher Relation in Canada”, The Canadian Journal of Economics, 30(4), 1124-1142.

Cumby, R.E. (1980), "Exchange-Rate Expectations and Nominal Interest Differentials: A Test of the Fisher Hypothesis", NBER Working Paper, No: 537.

Çakmak, E. \& H. Aksu \& S. Başar (2002), "Fisher Hipotezinin Türkiye Açısından Değerlendirilmesi: 1989-2001”, Atatürk Üniversitesi İktisadi ve İdari Bilimler Dergisi, 16(3-4), 31-40.

Çetin, M. \& F. Seker (2012), "Enerji Tüketiminin Ekonomik Büyüme Üzerindeki Etkisi: Türkiye Örneği”, Uludă̆ Üniversitesi İktisadi ve İdari Bilimler Fakültesi Dergisi, 31(1), 85-106.

Çil-Yavuz, N. (2006), "Türkiye'de Turizm Gelirlerinin Ekonomik Büyümeye Etkisinin Testi: Yapısal Kırılma ve Nedensellik Analizi”, Doğuş Üniversitesi Dergisi, 7(2), 162-171.

Daniels, J.P., F. Nourzad \& R.K. Toutkoushian (1996), "Testing the Fisher Effect as a Long-Run Equilibrium", Applied Financial Economics, 6(2), 115-120.

Demirag, I. \& S. Goddard (1995), Financial Management for International Business, USA: McGraw-Hill Co.

Dickey, D.A. \& W.A. Fuller (1979), "Distribution of the Estimators for Autoregressive Series with a Unit Root", Journal of the American Statistical Association, 74(366), 427-431.

Dickey, D.A. \& W.A. Fuller (1981), "Likelihood Ratio Statistics for Autoregressive Time Series with a Unit Root", Econometrica, 49(4), 1057-1072.

Dutt, S.D. \& D. Ghosh (1995), "The Fisher Hypothesis: Examining the Canadian Experience", Applied Economics, 27(11), 1025-1030.

Enders, W. (1995), Applied Econometric Time Series, New York: John Wiley \& Sons.

Engsted, T. (1996), "Non-Stationarity and Tax Effects in the Long-Term Fisher Hypothesis", Applied Economics, 28(7), 883-887.

Fisher, I. (1896), “Appreciation and Interest”, Publications of the American Economic Association, 11(4), 331-442. 
Fisher, I. (1930), The Theory of Interest: As Determined by Impatience to Spend Income and Opportunity to Invest It, USA: Kelley Publishing.

Graham, F.C. (1988), "The Fisher Hypothesis: A Critique of Recent Results and Some New Evidence", Southern Economic Journal, 54(4), 961-968.

Granger, C.W.J. \& P. Newbold (1974), "Spurious Regressions in Econometrics”, Journal of Econometrics, 2(2), 111-120.

Granville, B. \& S. Mallick (2004), "Fisher Hypothesis: UK Evidence Over a Century”, Applied Economics Letters, 11(2), 87-90.

Gupta, K.L. (1991), "Interest Rates, Inflation Expectations and the Inverted Fisher Hypothesis", Journal of Banking \& Finance, 15(1), 109-116.

Gül, E. \& S. Açıkalın (2008), “An Examination of the Fisher Hypothesis: The Case of Turkey”, Applied Economics, 40(24), 3227-3231.

Gültekin, N.B. (1983), "Stock Market Returns and Inflation: Evidence from Other Countries", The Journal of Finance, 38(1), 49-65.

Herwartz, H. \& H.E. Reimers (2006), "Modelling the Fisher Hypothesis: Wold Wide Evidence", CAU Working Paper, No: 2006-04.

Hutchison, M.M. \& M.C. Keeley (1989), "Estimating the Fisher Effect and the Stochastic Money Growth Process", Economic Inquiry, 27(2), 219-239.

Inder, B. \& P. Silvapulle (1993), "Does the Fisher Effect Apply in Australia?”, Applied Economics, 25(6), 839-843.

Ito, T. (2009), "Fisher Hypothesis in Japan: Analysis of Long-Term Interest Rates Under Different Monetary Policy Regimes", The World Economy, 32(7), 1019-1035.

Jaffe, J.F. \& G. Mandelker (1976), "The Fisher Effect for Risky Assets: An Empirical Investigation", The Journal of Finance, 31(2), 447-458.

Johansen, S. (1988), "Statistical Analysis of Cointegration Vectors", Journal of Economic Dynamics and Control, 12(2-3), 231-254.

Johansen, S. (1991), "Estimation and Hypothesis Testing of Cointegration Vectors in Gaussian Vector Autoregressive Models", Econometrica, 59, 1551-1580.

Johansen, S. (1995), Likelihood-Based Inference in Cointegrated Vector Autoregressive Models, Oxford: Oxford University Press.

Johansen, S. \& K. Juselius (1990), "Maximum Likelihood Estimation and Inference on Cointegration with Applications to the Demand for Money", Oxford Bulletin of Economics and Statistics, 52(2), 169-210.

Junttila, J. (2001), “Testing an Augmented Fisher Hypothesis for a Small Open Economy: The Case of Finland", Journal of Macroeconomics, 23(4), 577-599.

Kane, A. \& L. Rosenthal \& G. Ljung (1983), "Tests of the Fisher Hypothesis with International Data: Theory and Evidence", The Journal of Finance, 38(2), 539-551.

Kasman, S. \& A. Kasman \& E. Turgutlu (2006), "Fisher Hypothesis Revisited: A Fractional Cointegration Analysis", Emerging Markets Finance and Trade, 42(6), 59-76.

Kutan, A.M. \& T. Aksoy (2003), "Public Information Arrival and the Fisher Effect in Emerging Markets: Evidence from Stock and Bond Markets in Turkey", Journal of Financial Services Research, 23(3), 225-239. 
Lardic, S. \& V. Mignon (2003), "Fractional Cointegration between Nominal Interest Rates and Inflation: A Re-Examination of the Fisher Relationship in the G7 Countries", Economics Bulletin, 3(14), 1-10.

Linden, M. (1995), "Interest Rate and Inflation Expectations in Finland 1987-1994: A Case for the Inverted Fisher Hypothesis", Finnish Economic Papers, 8(2), 108-115.

Madsen, J.B. (2005), "The Fisher Hypothesis and the Interaction between Share Returns, Inflation and Supply Shocks".Journal of International Money and Finance, 24(1), 103-120.

Masih, R., \& A.M.M. Masih (1996), "Stock-Watson Dynamic OLS (DOLS) and Error-Correction Modelling Approaches to Estimating Long-and Short-Run Elasticities in a Demand Function: New Evidence and Methodological Implications from an Application to the Demand for Coal in Mainland China”, Energy Economics, 18(4), 315-334.

Mcdonald, R. \& P.D. Murphy (1989), "Testing for the Long Run Relationship Between Nominal Interest Rates and Inflation Using Cointegration Techniques", Applied Economics, 21(4), 439-447.

Million, N. (2004), “Central Bank's Interventions and the Fisher Hypothesis: A Threshold Cointegration Investigation”, Economic Modelling, 21(6), 1051-1064.

Mishkin, F.S. (1993), "Is the Fisher Effect for Real? A Reexamination of the Relationship between Inflation and Interest Rates", NBER Working Paper, No: 3632.

Moazzami, B. (1991), "The Fisher Equation Controversy Re-Examined”, Applied Financial Economics, 1(3), 129-133.

Olekalns, N. (1996), "Further Evidence on the Fisher Effect", Applied Economics, 28(7), 851-856.

Pelaez, R.F. (1995), “The Fisher Effect: Reprise”, Journal of Macroeconomics, 17(2), 333-346.

Peng, W. (1995), "The Fisher Hypothesis and Inflation Persistence: Evidence from Five Major Industrial Countries", IMF Woking Paper, No: 95/118.

Phillips, P.C.B. \& M. Loretan (1991), "Estimating Long-Run Economic Equilibria”, The Review of Economic Studies, 58(3), 407-436.

Phylaktis, K. \& D. Blake (1993), “The Fisher Hypothesis: Evidence from Three High Inflation Economies", Review of World Economics, 129(3), 591-599.

Saikkonen, P. (1991), “Asymptotically Efficient Estimation of Cointegration Regressions", Econometric Theory, 7(1), 1-21.

Stock, J.H. \& M.W. Watson (1993), “A Simple Estimator of Cointegrating Vectors in Higher Order Integrated Systems", Econometrica, 61(4), 783-820.

Summers, L.H. (1982), “The Non-Adjustment of Nominal Interest Rates: A Study of the Fisher Effect”, NBER Working Paper, No: 836.

Sun, Y. \& P.C.B. Phillips (2004), "Understanding the Fisher Equation”, Journal of Applied Econometrics, 19(7), 869-886.

Şimşek, M. \& C. Kadılar (2006), "Fisher Etkisinin Türkiye Verileri ile Testi”, Doğuş Üniversitesi Dergisi, 7(1), 99-111.

Tarı, R. (2005), Ekonometri, 3. Bask1, İstanbul: Kocaeli Üniversitesi Yayınları.

Turgutlu, E. (2004), "Fisher Hipotezinin Tutarlılığının Testi: Parçalı Durağanlık ve Parçalı Koentegrasyon Analizi”, Dokuz Eylül Üniversitesi İktisadi ve İdari Bilimler Fakültesi Dergisi, 19(2), 55-74. 
Wong, K.F. \& H.J. Wu (2003), “Testing Fisher Hypothesis in Long Horizons for G7 and Eight Asian Countries", Applied Economics Letters, 10(14), 917-923.

Woodward, G.T. (1992), "Evidence of the Fisher Effect from U.K.Indexed Bonds", The Review of Economics and Statistics, 74(2), 315-320.

Yılancı, V. (2009), "Fisher Hipotezinin Türkiye İçin Sınanması: Doğrusal Olmayan Eşbütünleşme Analizi”, Atatürk Üniversitesi İktisadi ve İdari Bilimler Dergisi, 23(4), 205-213.

Zivot, E. \& D.W.K. Andrews (1992), "Further Evidence on the Great Crash, the Oil-Price Shock and the Unit-Root Hypothesis”, Journal of Business \& Economic Statistics, 10(3), 251-270. 
Akıncı, M. \& Ö. Yılmaz (2016), "Enflasyon-Faiz Oranı Takası: Fisher Hipotezi Bağlamında Türkiye Ekonomisi İçin Dinamik En Küçük Kareler Yöntemi”, Sosyoekonomi, Vol. 24(27), 33-55. 